\title{
Materia y praxis
}

\author{
Jordi Corominas
}

A Ignacio Ellacuría

\section{Resumen}

La tesis que pretende sostener el autor en este artículo es que la principal virtualidad "liberadora" de la filosofía zubiriana está en la posibilidad de exprimir, a partir de ella, algunas de las intuiciones de la, llamada por Gramsci, "filosofía de la praxis" a las que ya apunta I. Ellacuría en sus últimos escritos y que lleva a término Antonio González. Para Ellacuría, Zubiri empieza siempre desde una realidad dinámica trascendental, y su mayor virtualidad liberadora consistiría en desarrollar una metafísica en la que tendría cabida la novedad histórica.

\section{Introducción}

I. Ellacuría, impactado y violentado por la realidad de sufrimiento y de miseria de la mayor parte de la sociedad salvadoreña y latinoamericana, buscó en la filosofía de Zubiri no sólo una satisfacción intelectual para los múltiples problemas e interrogantes que plantea la vida misma en todos sus órdenes, sino algunas virtualidades que pudieran contribuir a transformar la sociedad y a liberarla de un sufrimiento, una miseria y una dominación cultural que se impone como un hecho en América Latina. A este respecto, consideró que la principal luz que podía brindar la filosofía zubi- riana era la posibilidad de elaborar a partir de ella un materialismo metafísico abierto, menos idealista que el materialismo dialéctico, que no redujera la historia a la naturaleza y, sobre todo, que no la conceptualizara desde un esquema modernizante en la que es minimizada la responsabilidad humana. I. Ellacuría no se hace muchas ilusiones sobre la función del filósofo y de la filosofía, pero piensa que, al igual que cualquier otro saber, puede contribuir desde su propia especificidad a orientar aquellas acciones encaminadas a subvertir las estructuras imperantes de dominio, opresión y muerte. 
Ya en su tesis docioral "La principialidad de la esencia"' y en el curso "Estructura dinámica de la realidad", impartido por X. Zubiri en 1968, I. Ellacuría aprecia la posibilidad de asumir la historia como horizonte y objeto de la metafísica. Pero es sobre todo a raíz del curso inédito "La dimensión social, individual e histórica" que dio X. Zubiri en 1974, que se decide a reelaborar el materialismo abierto de ascendencia zubiriana. Su principal contribución a la liberación no estaría tanto en la elaboración de un nuevo materialismo, sino más bien en tomar la actividad histórica como objeto y punto de partida de la filosofía. La tesis que pretendemos sostener en este artículo, es que la principal virtualidad "liberadora" de la filosofía zubiriana está en la posibilidad de exprimir a partir de ella algunas de las intuiciones de la, llamada por Gramsci, "filosofía de la praxis" a las que ya apunta I. Ellacuría en sus últimos escritos y que lleva a término Antonio González ${ }^{2}$. Desde este plano intentaremos releer las tesis materistas de Zubiri. Pero para apreciar tanto la novedad como la continuidad de este planteamiento respecto a otras elaboraciones filosóficas, procederemos por partes. En primer lugar, trataremos de precisar en qué consiste el materialismo metafísico abierto de I. Ellacuría.

\section{El materialismo abierto}

El materialismo abierto que es posible hilvanar como tesis metafísica sobre la realidad a partir de la filosofía zubiriana consistiría, según I. Ellacuría, en un nuevo realismo metafísico apto para desligarse tanto del idealismo de la filosofía moderna como para reactualizar un realismo medieval o escolástico, que se habría fosilizado en logificaciones intelectivas ${ }^{3}$. En X. Zubiri no habría distinción enire filosofía primera y filosofías segundas, sino que la filosofía sin más debería tratar el todo de la realidad dinámicamente considerado. En este "todo", el dinamismo último sería la historia. Es por ello que I. Ellacuría afirmará que el objeto de la filosofía y su punto de partida es justamente la realidad histórica, pues es en la realidad histórica donde se daría la manifestación englobante de toda otra realidad y de todo dinamismo ${ }^{4}$. Este materialismo realista abierto a la historia humana sería especialmente útil para sustituir el materialismo dialéctico, que en la tradición marxista ha sido el compañero cosmológico más frecuente del materialismo histórico. El materialismo zubiriano sería polémico con las filosofías no materialistas o idealistas, pero a diferencia del materialismo dialéctico no cacría en una reducción de lo real a la materia entendida como corpúsculos y podría integrar mejor el papel activo y libre del ser humano en la configuración de la historia.

Lo que nos preguntamos es si esta concepción histórico-metafísica, con todo lo importante que pueda ser, es el aporte más significativo que cabe desprender de los trabajos zubirianos para una filosofía con pretensiones de transformación política y social. Uno podría legítimamente pensar, como creo que pensaba Ignacio Ellacuría, que una hipotética filosofía primera ${ }^{5}$ de carácter zubiriano será todo lo importante que se quiera o más que sus concepciones metafísicas y antropológicas, pero menos relevantes para una filosofía con intenciones prácticas a la que nos empuja y arrastra la misma realidad latinoamericana. Ahora bien, ies cierto que el único o más relevante alcance liberador del pensar zubiriano se dé en su materialismo abierto? No está nada claro. Es más, el problema que plantea el materialismo abierto, por más abierto que sea, es que necesariamente se parte de una concepción metafísica sobre el todo de lo real susceptible de cargar con muchos elementos que no necesariamente tiene que compartir una filosofía con intenciones liberadoras ${ }^{6}$. Sin embargo, justo

1. I. Ellacuría, "La principialidad de la esencia", Escritos filosóficos II. UCA Editores, 1999, p. 175.

2. A. González, Estructuras de la praxis, Ed. Trotta, 1997.

3. I. Ellacuría, “Aproximación a la obra completa de Xavier Zubiri”, ECA, San Salvador, 1983, pp. 421-422.

4. I. Ellacuría, Filosofía de la realidad histórica, UCA Editores, San Salvador, 1990, pp. 43-46.

5. A. Pintor-Ramos, Génesis y formación de la filosofía de Zubiri, Salamanca, 1983; D. Gracia, Voluntad de verdad. Para leer a Zubiri, Barcelona: Labor, 1986, son los que han introducido el término filosofía primera para distinguir en $X$. Zubiri niveles diferentes de radicalidad y fundamentalidad.

6. Incluso podría decirse que al considerar que el objeto de la filosofía es el todo de lo real, acercamos a la filosofía zubiriana a un cierto hegelianismo que lo expondría a las tendencias totalitarias de la filosofía occidental que tanto han subrayado Levinas y Dussel. Cfr. E. Dussel, Método para una filosofía de la liberación. Superación analéctica de la dialéctica hegeliana, Guadalajara, 1991. 
es reconocer que en los últimos escritos de I. Ellacuría se advierte una especic de desarrollo de su filosolía de la realidad histórica, que lo acerca a los planteamientos de la filosolía de la praxis.

\section{De una filosofia materialista abierta a una filosofía de la praxis histórica}

En "Función liberadora de la filosolía"7, I. Ellacuría considera que la filosofía, por su propia condición crítica, creativa y fundamentadora, tendría siempre una función liberadora y desideologizadora. Este potencial liberador propio de la filosolía para que sea realmente eficaz a la hora de transformar las estructuras sociales ha de contextualizarse, y en América Latina eso significaría insertarse adecuadamente en una praxis liberadora. Podrá disculirse que el dinamismo de la historia vaya hacia la libertad y la personalización, podrá discutirse cualquier tesis lilosólica, pero la necesidad de liberación de las culturas, los pueblos y las grandes mayorías de la humanidad se impondría como el hambre. De esta necesidad emergerían procesos de liberación, actividades, fuerzas sociales y grupos que tenderían a transformar la realidad histórico-natural produciendo un orden nuevo. Por más incipiente que fuera esta praxis, aunque sólo contuviera un momento de resistencia al orden opresor, sería adscribiéndose en ella como la lilosofía podría desempeñar una función liberadora eficaz en América Latina.

¿Cómo se insertaría adecuadamente, según I. Ellacuría, el ejercicio filosófico en esta praxis liberadora? En primer lugar, siendo consciente de sus límites y con pretensiones muy humildes. El error frecuente de los filósofos es el de pensar que interpretando el mundo lo están transformando cuando, de hecho, las ideas solas no cambian las cosas. Tienen que ser las fuerzas sociales las que lo hagan y estas fuerzas, luchas y resistencias no dependen de formulaciones filosóficas. En segundo lugar, preservando la independencia, la autonomía y el modo técnico y específico del filosofar para no convertirse en una dogmática o, lo que sería peor, en una filosofía popularizada o "ideología" liberadora. La fillosofía, como toda forma auténtica de saber, ha de mantener una cierta independencia

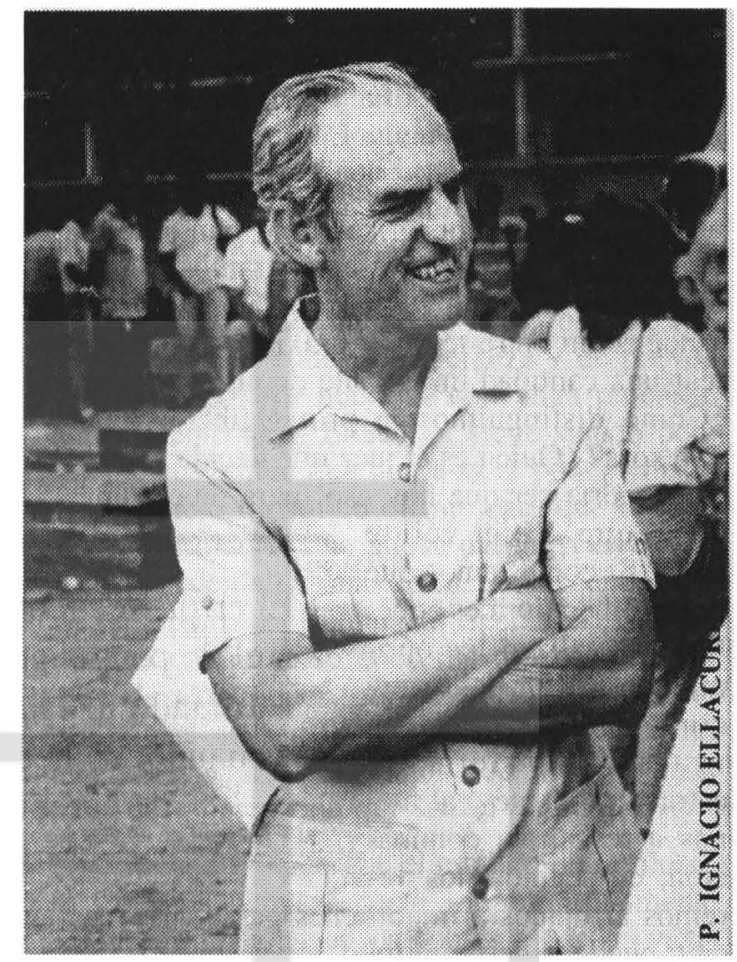

de la praxis dominante por más que sus enfoques orientadores dependan de la realidad social e histórica en que se realiza y del horizonte que enmarca esta realidad. En tercer lugar, acompañando la praxis liberadora con un bagaje teórico sobre puntos esenciales (teoría de la inteligencia, teoría de la realidad, teoría del hombre, la sociedad y la historia, la ética y la filosofía de la religión) en los que la filosofía latinoamericana no se habría expresado de una forma satisfactoria.

En resumen, se trataría de participar en la praxis liberadora con intensidad teórica y distancia crítica. El filósofo debería estar presente y participar en las luchas, acciones y actividades tendentes a transformar la sociedad en una dirección humanizadora y sobre todo integradora de las mayorías populares, pero su compromiso no debería llevarlo hasta engañarse en lo que es efectivamente liberador y lo que no lo es en estas actividades. Este equilibrio entre una existencia socrática proclive a la soledad,

7. Ignacio Ellacuría, "Función liberadora de la filosofía", Veinte años de historia en El Salvador, escritos políti$\cos$, Tomo I, UCA Editores, 1991, pp. 119-121. El mismo artículo en I. Ellacuría, "Función liberadora de la filosofía", $E C A$, enero-febrero, 1985, pp. 45-64. 
pero necesaria para que la filosofía conserve su mordiente crítico, y el compromiso proclive a la politización de la filosofía y el filósofo es al difícil equilibrio al que nos invita Ellacuría ${ }^{8}$.

Aunque indudablemente en este artículo se acentúa la praxis histórica como punto de partida de la tarea filosófica y encontramos claramente expresado la forma como concibió I. Ellacuría la vinculación entre teoría y praxis, no deja de plantear una cantidad importante de nuevas preguntas: ¿Cómo distinguimos la praxis liberadora de la opresora? ¿Quién es el juez que decide sobre esto? ¿No podría ser que hoy eso fuera mucho más oscuro que hace veinte años? Si contestamos que praxis liberadora es aquella que realizan los oprimidos, marginados y excluidos del sistema en vistas a transformarlo estructuralmente $o$ al menos a resistir la dominación, en seguida nos veremos arrojados a importantes paradojas. Esta acción puede ir desde el robo, los secuestros, los actos de sabotaje, los asesinatos, hasta la organización de cooperativas, partidos políticos, comunidades, vertebración con organismos no gubernamentales y no podemos estar seguros de que todas sean igualmente liberadoras ni que alguna de ellas efectivamente lo sea. Podría ser incluso que algunas de las acciones más aparentemente liberadoras fucran las mejores armas del sistema.

El mismo I. Ellacuría era consciente de que experiencias históricas aterradoras en el siglo XX, como el estalinismo o el fascismo, han sido originariamente pensadas como una praxis liberadora y como un "humanismo". Las monstruosidades realizadas bajo la bandera de la liberación imposibilitan hoy una confianza ingenua en cualquier acción pretendidamente liberadora. En cierto modo, la experiencia histórica centroamericana reciente intro- duce una desconfianza mayor que la que ya mantenía I. Ellacuría. Acciones y fuerzas, otrora ejemplares y pretendidamente liberadoras, apenas pueden esconder hoy, bajo su lenguaje revolucionario, la corrupción y la manipulación de los pobres. $\mathrm{Si}$ hegelianamente nos decidiéramos a decir que el juez que decide sobre qué praxis es liberadora es la misma historia, habrá que reconocer que la historia suele bendecir a los triunfadores" por más cargados de razón que estén los perdedores.

Otro problema, no siempre aclarado en los textos de 1. Ellacuría, es que si se privilegia en el punto de partida la praxis histórica, pareciera que estamos privilegiando dogmáticamente aquellas acciones que aparentemente hacen historia (organizaciones políticas, fuerzas sociales, organizaciones comunitarias, elc.) sobre las acciones que aparentemente no la hacen (cuidar el jardín, rezar, trabajar donde se pueda, etc.). Pero, aun suponiendo que algunas acciones tuvieran un privilegio liberador, la filosofía no puede darlo por supuesto. Más grave filosóficamente, si el criterio de autenticidad liberadora de una filosofía no depende de la filosofía misma, ¿no pierde ésta su radicalidad constitutiva? ¿No pasa la filosofía a medirse por una verdad exterior a sus propios resultados, contradiciendo su pretensión socrática de justificación radical de sus tesis y puntos de partida? La prioridad de la acción sobre la teoría, que en muchas filosofías de la praxis se da por descontado, no es algo que la filosofía deba asumir sin más, sino una tesis de índole metafísica u antropológica que tendrá que ser dilucidada filosóficamente. Es muy posible que una praxis liberadora se dé independientemente de todo análisis y reflexión filosófica, pero justamente, si algún sentido tiene la práctica filosófica es no dar por supuesto nada y mucho

8. Ignacio Ellacuría, "Función liberadora de la filosofía", Veinte años de historia en El Salvador, escritos polítiç̣s, Tomo I, UCA Editores, 1991, p. 113 y ss.

9. Como bien muestra Fukuyama en su artículo "El fin de la historia" de 1989. Diez años después Fukuyama aprieta las tuercas. En 1999 no sólo se mostraría que no hay una alternativa de modelo de desarrollo viable mundial, sino que estaríamos en ciernes de iniciar una historia posthumana al tener ya las herramientas para alterar, mediante la ingeniería genética, la conducta humana. Cfr. F. Fukuyama, The Great Disruption: Human Nature and the Reconstitution of Social Order, Angeles Times, 1999. 
menos el valor de verdad y de "liberación" de unas determinadas acciones y opciones.

La filosofía de la liberación latinoamericana ha discutido mucho este asunto, diferenciándose sus posiciones entre una vertiente que podríamos llamar universalista, que acentúa más la autonomía de la fïlosofía, y una vertiente hermenéutica, que acentúa su carácter contextual. El peligro de la vertiente universalista es el academicismo y la descontextualización. El peligro de la vertiente contextualizadora es que considere que la opción liberadora pertenece tan sustantivamente a la filosofía que sin ella sería imposible hacer buena filosolía. La opción y el contexto acabarían siendo más decisivos que el ejercicio filosófico riguroso mismo. Un cierto escepticismo sano, que exige el mismo ejercicio filosófico, nos lleva a elevar de grado la autonomía de la filosofía sin prescindir de su necesaria contextualización. Así, se podrá decir que la fraternidad con las víclimas de todo poder nos puede permitir hacer mejor filosofía, en la medida en que nos instalamos vivencialmente en una problemática que afecta a la mayor parte de la humanidad y que, en consecuencia, es más universal, pero no es ninguna garantía de ello. Es decir, aquí la opción y la praxis liberadora podrán ser humana y éticamente mucho más importantes que las disquisiciones filosóficas y tendrán también una relcvancia filos6́fica ${ }^{10}$, pero no son el núcleo ni lo sustantivo del discurso filosófico. La filosofía es un poco como el arte. No hay que prescribirle de entrada una eficacia, pues bien hemos aprendido que la mentira se introduce tambićn en la pretensión de ser útiles y edificantes.
El que ejercita la filosofía, como el que ejercita el arte, servirá con mayor seguridad a su tiempo si se preocupa por comprender la problemática interna de su disciplina y expresar lo más exigente de sí mismo. Una filosofía y una literatura comprometidas de entrada, quizás no expresen sino lo más gastado y anodino de la época, mientras que una literatura y una filosofía aparentemente "descomprometidas" alcanzan muchas veces, por su radicalidad, mayores cotas de esperanza y de porvenir. Sin embargo, por más que convenga repensar el planteamiento de I. Ellacuría, sigue siendo perfectamente sostenible que no basta el poder liberador del ejercicio filosófico mismo para que la filosofía dé de sí todo lo que puede dar de sí en orden a la transformación de unas estructuras sociales injustas. Para realizar el potencial liberador es indispensable el compromiso ético del filósofo con las víctimas de todo poder, por más que la praxis de estas víctimas no sea liberadora, por más que no sean agentes de transformación social y por más oscuro y desesperanzado que sea su futuro" .

En este sentido, creo que el estatuto de la filosofía en América Latina respecto a lo que usualmente se ha llamado opción por los pobres o por las víctimas de todo poder, es el mismo que el de los demás saberes $^{12}$ (sociología, arte, poesía, física, matemáticas, psicología, etc.). También el poeta, el físico o el psicólogo tienen élicamente la exigencia de no vivir en torres de marfil y es posible que una física, una psicología y una poesía comprometidas con las grandes mayorías de la humanidad sean mejor poesía, matemática y física, pero su "compromiso" no es ninguna garantía de ello. Ciertamente, una buena sociología, una buena poesía o una buena física no ne-

10. La relevancia filosófica de una forma de vida fraterna con las víctimas de todo poder consiste en que las víctimas revelan, más que nadie, la verdad real del sistema económico-político y cultural, institución o grupo en el que viven constituyendo así un principio de desideologización y, además, esta existencia fratemal, en la medida en que no sea cínica, es susceptible de liberar al filósofo y a su filosofía del afán de prestigio, poder y dinero. La fraternidad con las víctimas puede permitir hacer una filosofía más auténtica y "pura", en la medida en que el practicante de la filosofía ya no se ve lanzado a tener que defender ningún privilegio, ni tan siquiera los académicos.

11. La psicología nos muestra que no es siempre fácil hacer una distinción entre problemas personales y deseos de cambio. También hay que contar con la ambigüedad de toda acción, las crisis personales, la condición social, etc., pero todo esto lo que relativiza es la utilización de la ética como una arma arrojadiza o como vara de medida de los seres humanos, y no el hecho de una exigencia ética que nos incumbe a todos. Cfr. J. Corominas, "La fundamentación", Ética primera, aportación de X. Zubiri al debate ético contemporáneo, pp. 327-364.

12. Exceptuando quizás la teología cristiana, pues en ella el "pobre", "la víctima", "el crucificado", "el fracasado" más allá de toda justificación filosófica, ética o política, es su núcleo central. Cfr. R. Alvarado, “Teología de la liberación en el postsocialismo?”, Revista Latinoamericana de Teología, 47, mayo-agosto, 1999. 
cesariamente sirven a los intereses de las grandes mayorías. Sin una solidaridad efectiva del artista, el lilósofo, el científico o el técnico con las víclimas de todo poder, es difícil desprender de estos saberes alguna eficacia liberadora, pero convertir el compromiso ético en canon de verdad de estos saberes aún sirve menos a aquellos que en los estados, las instituciones y los grupos humanos sufren los laccrantes efectos del poder. La fraternidad con los excluidos de aquel que cultiva una de estas disciplinas ha de pasar por radicalizar su propio saber y tratar de mejorarlo so pena de no servir ni a los intereses de las grandes mayorías ni a los intereses de su propia disciplina. El compromiso con merma de la autonomía de los diferentes saberes fácilmente lleva a la idcología y a la servidumbre de un nuevo poder. La autonomía sin compromiso ético fácilmente lleva a un academicismo neutral que sirve al poder de siempre. Conjuntar las dos cosas es el reto siempre nuevo, difícil c inevitablemente disarmónico de universitarios y profesionales que se esfuercen por no estar al servicio de ningún poder sino al servicio de la verdad.

A lo largo de todo el texto utilizo indiscemidamente los lérminos: "mayorías de la humanidad", "pobres", "excluidos", "dominados", "víctimas de todo poder", sin encontrar satisfacción plena en ninguna designación. Tiendo a preferir la designación de "víctimas de todo poder" porque éstas están en todas partes y no es tan fácil alejarlas en el espacio y el tiempo de nuestras propias acciones, como si las mismas fueran inocentes. Hoy creo que son muy poco creíbles aquellas instituciones, partidos, grupos o personas que no se esfuerzan por poner en práctica en su casa lo que exigen fuera" ${ }^{13}$. El término "víctima" incluye fácilmente los demás términos posibles: explotado, oprimido, dominado, excluido, y expresa quizás mejor la duplicidad de nuestros roles: todos podemos ser al mismo tiempo víctimas ("sudacas"14 , emigrantes, mujeres, negros, obreros sin derechos, homosexuales, curas comunistas, etc.) y victimarios (machistas, racistas, autoritarios, explotadores, etc.). Es muy corriente que no seamos conscientes de nuestra condición de víctimas, pero todavía lo es más el no serlo de nuestra condición de victimarios.

El poder produce siempre víctimas y aunque pueda haber un mundo con víctimas desconocidas, no lo puede haber sin algún género de víctimas o algún grado de victimización en el transcurso de las vidas humanas ${ }^{15}$. Todo poder es siempre un arma de doble filo. El poder más liberador puede ser también el más opresor, piénsese en el poder materno-patemo o en el poder religioso, que al llegar a unas fibras humanas donde otros poderes no llegan, es capaz de agredir profundamente con las mejores intenciones ${ }^{16}$. El problema con el término

13. Es una de las contradicciones que señala José María Castillo en la Iglesia católica. Mientras el Papa proclama estos derechos, el Vaticano se niega a firmar o ratificar las convenciones generales sobre los derechos económicos, sociales, culturales, civiles y políticos. "Y la razón de este hecho es clara: la Iglesia católica, tal como está organizada y tal como en realidad funciona, no puede aceptar el texto íntegro de la Declaración Universal de los Derechos Humanos porque no puede aceptar la igualdad efectiva y real de hombres y mujeres. Ni la libertad de expresión y enseñanza sin recortes. Ni las garantías jurisdiccionales en el enjuiciamiento y medidas disciplinarias. Ni la participación de todos los miembros de la Iglesia en la designación de los cargos eclesiásticos”. J. M. Castillo, Iglesia y derechos humanos, Madrid: Nueva Utopía, 1999, p. 18.

14. Término despectivo con el que algunos españoles designan a los emigrantes provenientes de América Latina.

15. Así lo aprecia también M. Foucault. Es importante resaltar que en sus últimos escritos reivindica una distancia crítica de la actividad racional respecto a las relaciones, el control y la disciplina del poder en el que siempre estamos. De ese modo, su análisis de los mecanismos de poder no es exactamente fruto de una internalización de las relaciones de poder, sino de una libertad crítica que tiende a promover una comprensión de cómo podríamos gestionar este poder de modo que hubiera menos sufrimiento. Cfr. M. Foucault, Dits et écrits, 1980 1988, París: Ed. Gallimard, Tomo IV, 1994.

16. Un esfuerzo por conceptuar la relación entre poder e instituciones puede verse en J. Corominas, "La acción humana, reproducción y transformación del sistema mundial", Diakonia, Nicaragua, 78, junio, 1996. 
"víctima" es que tiende a ontologizar la condición de víctima y a crear una dicotomía entre víctimas y viclimarios, cuando en realidad esta división atraviesa, en muy diferente grado y responsabilidad, claro está, toda vida humana. En este sentido, el calificativo de "víctima" suele implicar una sórdida autosatisfacción de occidente, de los ricos, de los que quieren ayudar y pretenden hablar en nombre de otros, y una sustracción de la capacidad humana, afirmativa, responsable y creadora de los calificados como "víctimas"17. Y es que la ética no se funda propiamente en el reconocimiento de las víctimas ${ }^{1 / R}$ sino, sobretodo, en un dinamismo de alteridad que nos arrastra y nos impele a compenetrarnos con los demás seres humanos y hasta con los demás seres vivos y la naturaleza, más allá de toda designación abstracta y de todo consenso o utilidad. Más allá, incluso, de los intereses de la humanidad ${ }^{19}$

En cierto modo, la disciplina que cruza ortogonalmente todos los saberes y todas las acciones humanas es la ética. La exigencia ética universal, que afecta a todos los seres humanos, descansa sobre una experiencia religativa ${ }^{20}$ que no le quita ni añade nada a esta exigencia, pero sí que le da una sonoridad y una actitud que, en cierto modo, lo cambia todo. Así, por ejemplo, entre la impresionante diversidad de experiencias religativas teístas, ateas, agnósticas o indiferentes, la experiencia cristiana de Dios que a trancas y a barrancas van realizando los cristianos a lo largo de su vida, cargando con su psicología, su extracción social y su cultura, libera la exigencia ética del considerarse meritorio por responder a ella, de la amargura del espíritu de camello y de león que tan bien describe Nietzsche ${ }^{21}$, del miedo al fracaso, del convertir a los otros en instrumentos de nuestro prestigio, y de la pretensión de ser eficaces, pero también de toda gracia barata, de toda santurronería y de todo miedo al conflicto y a mantener posiciones duras ${ }^{22}$. En cualquier caso, la ética suele ser un campo abonado para satisfacer la

17. Es, entre muchos otros y otras, la crítica que desarrolla A. Badiou a las éticas que parten del reconocimiento de la víctima. Cfr. A. Badiou, L'éthique, essai sur la conscience du Mal, Hatier, París, 1993, pp. 11-17.

18. Ni aún en E. Dussel, donde este reconocimiento desempeña una función muy importante, es el principio ético fundamental, sino la obligación de desarrollar y reproducir la vida humana. Cfr. E. Dussel, Ética de la liberación en la edad de la globalización y de la exclusión, México: Ed. Trotta, 1998. p. 376 y ss.

19. Si efectivamente se da este dinamismo, cómo hay que entenderlo, cómo se vertebra con otros hechos primordiales y cómo se contextualiza en la actualidad es lo que trato de explorar en mi tesis: Cfr. J. Corominas, Ética primera, aportación de X. Zubiri al debate ético contemporáneo, Tesis doctoral, UCA, pp. 351-352.

20. Cfr. Jordi Corominas, "Religación y obligación", Érica primera, op. cit., p. 332 y ss.

21. Cfr. J. Corominas, "El Anticristo de F. Nietzsche como propedéutica de la fe cristiana", Revista Latinoamericana de Teología, 46, San Salvador, 1999.

22. En cada cristiano, en medio de todas sus ambiguiedades, podemos encontrar alguna pincelada de ello. La ternura y la risa no van reñidos con la profecía, el grito y la denuncia. La poesía y la vida de Pedro Casaldáliga SON un entrañable ejemplo de ello:

Voy a pasar la vida

más o menos inútil,

más o menos poeta.

No habré tenido un hijo.

No habré sido magnate ni gerente de lucros,

ni albañil o mecánico.

Habré plantado unos contados árboles

y habré escrito unos libros, muchas cartas,

hojas hijos al viento.

-Procura que la Gracia y la Ternura

llenen de vino nuevo...

tu ánfora de barro.

Dios mide a su manera la eficacia.

Ama a todos los hijos de los hombres.

Cfr. P. Casaldáliga, Todavia estas palabras, Verbo Divino, Navarra, 1989, p. 44. 
pretensión de universalidad de la filosofía. No es de extrañar que la lilosofía de la liberación se haya reducido muchas veces a ser una ética filosófica ${ }^{23}$.

El esfuerzo por fundamentar una élica verdaderamente universal y una exigencia de justicia que nos obliga a todos, sería una de las contribuciones lilosóficas más importantes que pueden esperarse para aquellos que sufren en carne propia la injusticia ${ }^{24}$. Pero aún en este terreno hay que introducir dos importantes salvedades. La primera es que la ética, en la medida que es una disciplina que cruza ortogonalmente todos los campos, es un asunto que compete tambićn a todos los saberes y en el que la filosofía sólo puede aportar su granito de dilucidación crítica y de csfuerzo de fundamentación. Tan difícil y complejo es para la ética un esfuerzo de fundamentación como uno de aplicación. Para una élica aplicada sucle ser inucho más importante lo que puede aportar el especialista de una determinada área que la disciplina filosófica en cuanto tal. Propiamente, las élicas aplicadas sólo pueden realizarse con el concurso de todos los saberes, cada uno desde su propia especilicidad. Una ćtica aplicada sin un esfuerzo de fundamentación queda colgada en el vacío, pero una fundamentación sin un desarrollo de éticas aplicadas es a todas luces insuficiente e inútil.

La segunda salvedad es que la filosofía no puede reducirse a una ética so pena de convertirse en un moralismo disfrazado y de hacerle un flaco favor a la búsqueda de una posible orientación universal a las acciones humanas. Cuanto más logra liberarse el ejercicio filosófico de intereses políticos y morales inmediatos y de su pretensión de influencia social, más interesante y más influyente suele ser política y socialmente. El potencial más genuinamente liberador de la filosofía empieza a perderse cuando éste consiste en confirmar nuestras inclinaciones, proyectos u opciones. El pragmatismo de cortos alcances que se quiere ligar inmediatamente a cuestiones prácticas puede perfectamente ser la mayor pérdida de tiempo. Y nada más práctico en momentos de oscuridad que el lento, paciente y aparentemente inútil esfuerzo filosófi$\mathrm{co}^{2.5}$. Lo mismo podemos decir de una sociología o de cualquier otro saber. De nada nos sirve una ciencia social crítica que además de un momento ético no desarrolle una teoría social potente.

Al tratar de claborar una filosofía de la praxis que se sostiene por un esfuerzo de radicalidad filosófica y no por algún género de interés moral, dogmatismo o arbitrariedad, podríamos satisfacer a cabalidad la brega intelectual misma de $\mathbf{I}$. Ellacuría, desprendiendo a una filosofía con pretensiones liberadoras de su exceso de equipaje y sometiendo a una profunda revisión tanto el materialismo metafísico como el materialismo histórico. Veámoslo suscintamente.

\section{El materialismo metafísico en la historia de la filosofia}

En la tradición filosófica occidental a lo largo de 2500 años, se ha entendido usualmente por materialismo una tesis metafísica: todo lo real es material, independientemente de como se defina luego eso que deba entenderse por materia en los atomistas y sofistas griegos, en los mecanicistas $c$ ilustrados del siglo XVII y XVIII, en el materialismo del siglo XIX, en el materialismo dialéctico $y$ en el materialismo emergentista del siglo $\mathrm{XX}$. Para el materialismo mecanicista decimonónico, la tesis de que todo lo real es material significa que lo que se ha llamado espíritu, mente, sentimientos, ideas, etc., es reducible a fenómenos físico-químicos. A partir de un modelo mecánico comprendieron el mundo como un compuesto de partículas materiales que se combinaban entre sí de un modo inerte. A este tipo de materialismo le es especialmente difícil explicar no sólo las características y propiedades de los seres humanos y de los sistemas sociales, sino de los sistemas vivos en general.

El materialismo dialéctico tiene la virtud de introducir la dinamicidad y el cambio en el corazón

23. E. Dussel, Érica de la liberación en la edad de la globalización y de la exclusión, México: Ed. Trotta, 1998.

24. A. González, "Fundamentos filosóficos de una civilización de la pobreza", $E C A, 583,1997$, pp. 417-426.

25. Irónicamente Gramsci dirá que los pragmáticos vulgares lo máximo que consiguen es crear movimientos como el del Rotary Club, mientras que autores peyorativamente tildados de idealistas y teóricos como Hegel pueden ser considerados como los precursores de las revoluciones liberales del siglo XIX. El esfuerzo teórico sería así un pragmatismo de largo alcance. El aforismo de Leibniz: quo magis speculativa, magis práctica algo de verdad debe de contener. Cfr. A. Gramsci, El materialisme històric i la filosofia de Croce, Barcelona: Editorial Laia, 1983, p. 91. 
de la materia, y de reconocer que en ciertas etapas de todo proceso emergen nuevas propiedades sin necesidad de reducir la materia a componentes fisico-químicos. Los fenómenos materiales son considerados aquí como procesos dinámicos. Lo más oscuro del planteamiento dialéctico es esta tesis tan antigua de que todos los opuestos luchan entre sí, conflicto que da como resultado el aniquilamiento de uno de ellos o la emergencia de un nuevo objeto que los sinteliza en una etapa de desarrollo supcrior. La "negación dialéctica", como clave del desarrollo y de la evolución, es una tesis melafísica que dista mucho de ser plausible contrastada con los conocimicntos científicos contemporáncos ${ }^{26}$. Aunque Marx lo que estudia es propiamente los sistemas sociales, el materialismo dialéctico es asumido por el marxismo ortodoxo como complemento natural de los estudios marxistas, y ello ha llevado frecuentemente al marxismo a convertirse en una forma de economicismo y determinismo: la historia estaría regida por leyes cconómicas sobre las cuales los hombres no tienen ningún poder y la humanidad estaría de alguna manera sometida a un proceso ciego independiente de la voluntad de quienes participan en ella.

Por su parte, el materialismo emergentista sostiene que lo psíquico o mental es una propiedad emergente que sólo poseen los animales dotados de sistemas neurales de gran complejidad. A diferencia de otros materialismos, es compatible con una ontología que proclama la variedad cualitativa y la mutabilidad de la realidad. Pero, como veremos, a diferencia del materismo zubiriano no emerge en el ser humano ninguna propiedad radicalmente innovadora respecto a otras especies animales con una organización estimúlica de gran complejidad $^{27}$. Lo psíquico es una esfera de realidad con propiedades irreductibles a lo físico-químico, aunque sin llegar nunca a formar una esfera autónoma. Lo mental brota de lo físico y depende de ello permanentemente.

Es muy importante deslindar todas estas teorías metafísicas materialistas de perspectivas e intereses morales emancipatorios. Eticamente el materialismo, como el idealismo, ha dado para todo. A veces, en las tesis materialistas ha latido un afán

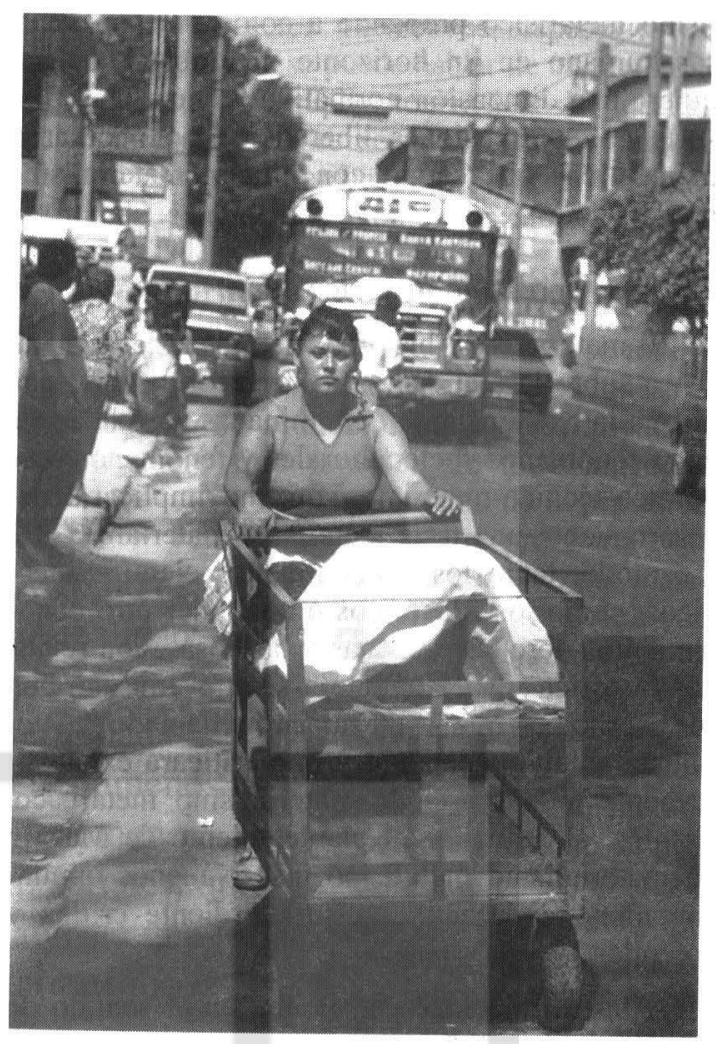

de liberar al ser humano de ideas, coacciones, prejuicios, dogmas hipostasiados y un afán de aceptación de la propia finitud y fragilidad, pero también ha latido en ellas justo lo contrario: las fantasías, los ideales y las monstruosidades más lamentables. En ocasiones, el materialismo ha tenido consecuencias políticas revolucionarias. Por ejemplo, el materialismo del siglo XVIII vació los mitos con que se justificaba el antiguo régimen. Pero también ha tenido una función reaccionaria al sujetar al ser humano a las leyes y determinismos de la naturaleza. Así, será muy frecuente que diversos autores materialistas hallen en la naturaleza un principio que suplante el Dios de algunas teologías y que aparezca en ellos una especie de nuevo estoicismo: "Que el hombre soporte sin murmuración las decisiones de una fuerza universal, que ni puede cambiar su rumbo ni desviarse nunca de las normas que su esencia le prescribe"28. El materia-

26. Cf. M. Bunge, "Crítica de la dialéctica", Materialismo y ciencia, Ariel, 1981, p. 57 y ss.

27. Cfr. M. Bunge, Filosofia de la psicologia, Ariel, 1988.

28. Cfr. Holbach, Sistema de la naturaleza, Berlín, 1960, p. 11. 
lismo metafísico propende a colocar de nuevo al ser humano en un horizonte naturalista que adquiere una dimensión normativa y ética. Una filosofía con pretensiones liberadoras no necesariamente tiene que cargar con ningún materialismo metafísico.

\section{El materialismo histórico}

El materialismo histórico no es una tesis metafísica sobre la realidad, sino una teoría social que afirma la existencia de determinadas correlaciones entre fenómenos socioculturales y fenómenos económico-técnico-materiales, que no implicaría necesariamente una tesis metafísica materialista. De cse modo, tanto los conocimientos científico-técnicos, como los filosóficos o cualquier otro conocimiento sobre las personas y las cosas, son relativos histórica y socialmente ${ }^{2 y}$. Gramsci insistirá en sus escritos en que Marx nunca ha llamado "materialista" a su concepción y que criticará exhaustivamente toda suerte de materialismo metafísico. Es más, al reducirse el planteamiento de Marx a un materialismo metafísico más o menos omniabarcador, se desactivaría su mordiente crítica y polémica.

A las afirmaciones de Lenin, en el sentido de que hay una realidad objetiva que existe independientemente del hombre que es a lo que propiamente podemos llamar materia ${ }^{30}$, Gramsci opondrá el reproche de Marx al materialismo metafísico, en el sentido de que sigue concibiendo la materialidad bajo la forma de objeto de la intuición sensible, pero no como actividad humana material, como práctica ${ }^{3 !}$. Gramsci es consciente que poner en tela de juicio la existencia del mundo exterior produce risas, pero lo reaccionario no es plantearse este problema, sino basarse en estas risas y en el sentido común para destruir la problematicidad de esta existencia ${ }^{32}$."El concepto "objetivo" del materialismo metafísico parece que quiere decir una objetividad que existe también independientemente del ser humano; pero cuando se afirma que una realidad existiría si no existiese el hombre, o se hace una metáfora o se cae en una forma de misticismo" "33. Si el idealismo hipostatiza el espíritu, el materialismo hipostatiza la materia y, justamente, la filosofía de la praxis busca sorprender en el punto de partida un momento que no suponga la reducción del espíritu a materia o de la materia al espíritu.

La preocupación decisiva de Marx no sería en una línea hegelianizante la inconsciencia de los seres humanos respecto a una realidad material objetiva cuyo dinamismo los determina, sino la inconsciencia de los seres humanos respecto al carácter social y enajenante de su propia actividad. Es este momento de inconsciencia el que asemeja los procesos sociales a los procesos de la naturaleza, sustrayendo a la historia de la intervención consciente de la humanidad. Lo más decisivo para la vida y la muerte, el sufrimiento y el bienestar de los seres humanos, los fines a menudo inconscientes de la actividad humana en todos sus órdenes, es sustraído de la conciencia de los hombres. Para dar a la materia lo que es de la materia y al hombre lo que es del hombre, Marx defiende el carácter activo del sentir humano. El momento de verdad del idealismo estaría en salvaguardar la función activa y responsable del ser humano. Su dificultad está en pensar este momento de un modo abstracto, desligado del sentir.

En el idealismo hegeliano ${ }^{34}$, la sensibilidad aparece como el saber más pobre y abstracto y sólo enriqueciéndola con el movimiento dialéctico

29. "La materia no ha de considerarse, pues, como tal, sino como social e históricamente organizada para la producción, y la ciencia natural, por tanto, ha de considerarse esencialmente como una categoría histórica, una relación humana". A. Gramsci, Introducción al estudio de la filosofia, Barcelona: Crítica, 1985, p. 123.

30. Cfr. V. Lenin, Materialismo y empiriocriticismo, México: Grijalbo, 1967, p. 99.

31. Cfr. K. Marx, Tesis sobre Feuerbach, UCA Editores, San Salvador, 1988.

32. Cfr. A. Gramsci, El materialisme històric y la filosofía de Croce, op. cit., p. 201 y ss. También M. Bunge adopta aquí esta estrategia argumental que denuncia Gramsci: "Quien niegue estas tesis realistas carece de experiencia en el control experimental de nuestros modelos conceptuales de las cosas, y no puede explicar la historia de la ciencia. Y lo que es peor: corre el riesgo de que lo lleven al psiquiatra". Cfr. M. Bunge, R. Ardila, Filosofía de la psicología, Ariel, 1988. Habría que decir, como es el caso de Gramsci, que también se corre el riesgo de que lo lleven a uno a la cárcel.

33. Ibid., p. 60.

34. Cfr. L. Hegel, Fenomenología del Espíritu, México: FCE, 1981, p. 63. 
de la percepción, el entendimiento, la autoconciencia, la razón y el espíritu se libra la sensibilidad de su abstracción y vaciedad. La filosofía posthegeliana hará un largo camino hasta llegar a conceptualizar al sentir humano como el saber más rico y más concreto. En Feuerbach, la sensibilidad adquiere una gran relevancia, pero subsiste una concepción objetivista de la misma. La sensibilidad humana se considera como un receptáculo pasivo o reflejo del mundo exterior y es igualada con la sensibilidad animal que se caracteriza precisamente por tener aprehensiones objetivas ${ }^{35}$.

El momento de verdad del materialismo es la primacía olorgada a la sensibilidad, pero su delecto es considerarla como una facultad pasiva. Marx crilicará precisamente esta concepción objetivista de la sensibilidad como un residuo idealista en la conceptuación de la misma, pues ésta, por más que reivindicada, queda como una facultad "contemplativa" de lo real, olvidando que la sensibilidad humana es ante todo actividad sensorial, "praxis". Finalmente en X. Zubiri llegamos al extremo contrario de Hegel, el sentir es el único y verdadero origen de la verdad y de las ideas. El conocimiento, la razón, el lenguaje serán meros sucedáneos del sentir humano ${ }^{36}$. La escisión entre sentir e inteligir, que recore la entera historia de la filosofía occidental, es eliminada de cuajo y la sensibilidad recupera el puesto de honor de los análisis filosóficos. Sin embargo, en la medida en que los análisis zubirianos han tendido a desgajar y privilegiar los actos intelectivos respecto a los volitivos y afectivos, se puede hablar de un prejuicio "inteleccionista". La superación radical del idealismo, de la escisión entre sentir e inteligir, hallaría quizás no tanto su culminación en Zubiri como en la filosofía de la praxis de Antonio González ${ }^{37}$.

\section{Filosofía primera como filosofia de la praxis}

La praxeología de Antonio González se muestra apta no sólo para librarnos de prejuicios intelectualistas y de reduccionismos naturalistas y cosmológicos, sino también de todo antropocentrismo de la praxis. $Y$ es que el problema filosófico decisivo del materialismo histórico de Gramsci está en que, en su combate contra el materialismo metafísico, se acaba sustituyendo un punto de partida metafísico por un punto de partida antropológico o sociológico. Por más importantes que sean las tesis antropológicas y sociológicas para transformar la realidad, éstas pueden ser siempre objeto de las mismas críticas a las que Gramsci somete las tesis metafísicas. La intuición original de la filosofía de la praxis en la que se insiste en que el punto de partida no es la naturaleza ni el hombre, sino las formas de intercambio de éste con la naturaleza y con sus semejantes (praxis), pierde parte de su criticidad constitutiva en el momento en que este punto de partida es entendido antropológica o sociológicamente. Y, ciertamente, puede decirse que las filosofías de la praxis, en la medida en que han subrayado el pa-

35. Cfr. D. Gracia, "Materia y sensibilidad", Realitas II, Madrid, 1976, pp. 203-243. En X. Zubiri mientras lo "objetivo" en el animal se autonomiza y es independiente respecto a la respuesta del proceso sentiente, la "alteridad" o "reidad" de la sensibilidad humana se autonomiza y es independiente respecto al entero proceso sentiente. Las cosas quedan tan "otras", tan "de suyo" en el sentir que, a diferencia del objetivismo animal, ni siquiera les pertenece su inclusión en el sentir. Cfr. X. Zubiri, Inteligencia y realidad, Alianza Editorial, Madrid, 1980, p. 61 y ss.

36. El logos y la razón podrán ganar en exactitud y rigor, pero la mayor riqueza y la intelección "superior" es la de los sentidos que aprehenden realidad. Cfr. X. Zubiri, Inteligencia y razón, Madrid: Alianza Editorial, 1983, p. 316.

37. Todas estas afirmaciones sobre la sensibilidad en $X$. Zubiri y la superación del idealismo que aquí aparecen muy escuetas, rotundas y poco matizadas, las he tratado de justificar en mi tesis doctoral. Cfr. J. Corominas, Érica primera, op. cit 
pel del sujeto como causa y origen de nuestros actos, además de incurrir en el peligro de ciertas idealizaciones voluntaristas o activistas, no consiguen salir del horizonte hegeliano del sujeto. Es la crítica fundamental de Habermas a las filosofías de la praxis. Habermas caracteriza la filosofía moderna como una filosofía del sujeto, cuyas raíces estarían en Descartes. El sujeto autónomo moderno no consigue reconciliarse con los otros y con las cosas, y para salir de esta escisión lípicamente ilustrada, la izquierda hegeliana propondría una filosolía de la praxis histórica, como proceso de desenajenación, y la derecha hegeliana una recuperación de la religión tradicional, como medio de unión entre los seres humanos y las cosas ${ }^{38}$.

Habermas intenta, entonces, desmarcarse del horizonte moderno del sujeto, reconstruyendo el materialismo histórico a partir de la praxis lingüística que constituiría un punto de partida intersubjetivo y social $^{\prime \prime}$, pero quedaba en cierta medida otra posibilidad que es tomar como punto de partida, como filosofía primera, no los actos lingüísticos, sino todo lipo de actos. Es el camino que recorre Antonio González. Gramsci acaba concibiendo la filosofía de la praxis como una filosofía del acı, "pero no del acto puro, sino precisamente del acto impuro, real en el sentido más profano y mundano de la palabra" ${ }^{40 .}$. Será mérito de A. González esclarecer filosólicamente en qué consiste el sentido profano y mundano de la realidad de los actos humanos.

Antonio González nos muestra cómo el ímpetu lïlosófico de X. Zubiri, la voluntad de justificación radical del punto de partida, culmina en una filosofía de la praxis, en una praxeología. A. González conecta la tradición fenomenológica radicalizada por X. Zubiri con el esfuerzo de los filósofos de la praxis para dar filosóficamente cuenta de su punto de partida. La praxeología sería el lu- gar de confluencia entre una filosofía de la praxis, que abandona demasiado rápidamente la justificación de su punto de partida, y una tradición fenomenológica, siempre sujeta a una cierta subjetividad y anhelo de apodicticidad. Su gran virtud es la de evitar constituirse en un sistema dogmático de verdades eternas o absolutas y el tomarse absolutamente en serio la afirmación gramsciana de que toda verdad, incluidas las de la misma filosofía de la praxis, es un valor provisional ${ }^{41}$. En este esfuerzo analítico eliminamos incluso la carga metafísica que ha adquirido la noción de praxis, bien por su adscripción a una teoría metafísica o bien por presuponer una teoría del sujeto. Lo decisivo es que las posiciones de una praxeología y de su papel emancipador y liberador, no se pueden refutar por el camino de las especulaciones o de las demostraciones, sino por el camino del análisis de los actos o de un mejor análisis de los mismos.

Más que reposar en algún argumento pragmático o ético-político, la praxeología dirige todo su empeño a justificarse filosóficamente, esto es, a tratar de resistir la crítica filosófica y a demostrar su temple en esta crítica. Podría ser que el objeto más propio del filosofar no fueran los actos, sino la praxis histórica o el sistema trascendental y dinámico de la realidad de I. Ellacuría, la noología de X. Zubiri, la tradición de H.G. Gadamer, la terapia del lenguaje de L. Wittgenstein, los actos lingüísticos de K.O. Apel y J. Habermas, la escritura y los textos de J. Derrida. En cualquier caso, habrá que argumentarlo filosóficamente, huyendo de todo género de dogmatismo. Las discusiones filosóficas se vuelven un poco pueriles cuando nos andamos por las ramas de sus sistemas o construcciones, pero se vuelven absolutamente apasionantes cuando se intenta discutir la raíz o punto de partida de los mismos ${ }^{42}$. Y es que hay algunos

38. Cfr. J. Habermas, "La prosecución del proyecto de Hegel en términos de filosofía de la praxis", El discurso filosófico de la modernidad, Madrid: Taurus, 1989, pp. 79-98.

39. Cfr. J. Habermas, La reconstrucción del materialismo histórico, Madrid: Taurus, 1981. El problema de este camino es que no se cuestionará el dogma del carácter esencialmente lingüístico de toda verdad que comparte una buena parte de la filosofía contemporánea occidental actual. Cfr. A. González, Estructuras de la praxis, op. cit., p. 29.

40. Cfr. A. Gramsci, Introducción al estudio de la filosofia, op. cir., p. 185.

41. Ibid., p. 164.

42. X. Zubiri nos enseña que el diálogo más fecundo en filosofía no se da discutiendo uno u otro momento del pensamiento de un filósofo, sino su punto de partida. En el primer paso se juega la suerte de la filosofía, aunque este paso sea el último que dé el que ejercita la filosofía en su aventura intelectual. $C f r$. X. Zubiri, Naturaleza, Historia, Dios, Madrid: Alianza Editorial, 1987, p. 282. 
dogmatismos filosóficos que a veces se esconden detrás de una aparente tolerancia. Uno de ellos consiste en elegir y defender, entre todo el impresionante muestrario de las construcciones filosóficas, aquel método o aquella teoría que se acomoda más a nuestros gustos o intereses. Otro, en negarse a argumentar y a poner en cuestión el entero edificio de una filosofía ${ }^{47}$. También entraña un dogmatismo decidir sobre el objeto de la filosofía por las consecuencias buenas o peligrosas que pueda tener.

Creo que lo más importante de la praxeología, más aún que su propio punto de partida, es la recupcración del aliento que desde sus inicios es vital para el esfuerzo filosófico: la búsqueda permanente de su propio objeto. A diferencia de las ciencias positivas que empiezan ya su propia tarea en un campo determinado, la filosofía tiene que empezar siempre conquistándolo palmo a palmo ${ }^{44}$. "Podría resultar que la filosofía fuera una pasión inútil y que el filósofo desfalleciera en la búsqueda de su objeto, al percatarse de que al cabo de los caminos no hay nada que justificase su esfucrzo y su pretensión. Pero su pretensión no por eso sería inútil, porque su propio fracaso diría de la realidad mucho más de lo que otros éxitos pretenden decir" 45 . El fracaso en filosofía es mucho más productivo que la adscripción a una moda, la apelación a argumentos de autoridad o a consideraciones políticas, culturales o de gusto extemporáneas al ejercicio filosófico mismo. En este permanente volver a empezar, en este esfuerzo de criba de los prejuicios en los que inevitablemente estamos, en esta pasión o ímpetu, la praxeología de Antonio González se convierte en una filosofía verdaderamente autónoma, original y radical realizándose las pretensiones de Gramscid $^{46}$ y evitando el peligro de convertirla en una "sociología" de algún materialismo metafísico. Eso no significa que una teoría materialista metafísica no sea importante, pero de alguna manera todas las teorías metafísicas quedan relativizadas al ser ancladas en una filosofía primera de la praxis.

\section{El carácter material de los actos}

Si analizamos los actos humanos poniendo entre paréntesis el sentido que siempre va ligado a ellos (logos: percepciones, emociones, actuaciones), lo que tenemos elemental y primariamente son notas de diferente indole: afectivas (me siento a gusto o a disgusto), volitivas (me rasco, me levanto) y sensitivas (color, tamaño, etc.). Nota es pura y simplemente lo

43. Es una paradoja especialmente sentida en algunos autores como J. Derrida. Por un lado, se interpela toda la historia de la metafísica; por el otro, esta interpelación es un juego que se hace en nombre de nada y que se afirma no mediante tesis sino "en una cierta carcajada y en un cierto paso de danza". J. Derrida, Marges de la philosophie, París, 1972, p. 29.

44. "Las ciencias no pueden menos que escandalizarse ante esta pretensión de la filosofía de buscar un objeto distinto de todo otro objeto y presente a todo otro objeto, así como ante el permanente balbuceo en que parecen moverse cada una de las filosofías". I. Ellacuría, "La idea de filosofía en X. Zubiri", Escritos filosóficos II, UCA Editores, San Salvador, 1999, p. 381. Esta es toda la grandeza y toda la miseria de la verdad filosófica. Léase con detenimiento el extraordinario resumen que hace I. Ellacuría del "objeto de la filosofía" en $X$. Zubiri. pp. 378-383.

45. I. Ellacuría, "La idea de filosofía en X. Zubiri", Escritos filosóficos II, UCA Editores, San Salvador, 1999, p. 379. Este talante ha sido en nuestro siglo reivindicado sobre todo por la fenomenología y, por supuesto, por Ortega y Zubiri, que partieron de ella en su aventura filosófica. Pero no es algo que identifique esta corriente. Es más, este talante lleva a cuestionar muchos de los resultados de aquellos autores que no han dudado en autocalificarse de fenomenólogos. Este talante es la fuerza de la fílosofía misma y podemos decir con Platón que está inscrita en el corazón de lo humano. Platón, Fedro, 980 a 21.

46. Ibid., p. 73. 
presente en los actos humanos ${ }^{47}$. Todo lo presente en los actos humanos, incluidos los aclos humanos cuando estos son objeto de otros actos, se nos presenta con un determinado contenido y con una determinada formalidad: lo presente, además de tener tales o cuales características, queda como siendo "de suyo" en los acıos mismos. Las cosas quedan remitiendo a sí mismas en una especie de autonomía o de alteridad. Lo que nos importa subrayar con el término nota es que no implica una referencia a algo externo a los actos humanos, ni a un sujeto de la que sean inherentes como son propensos a sugerir los términos "cualidad" o "propiedad". Las notas están presentes en toda su inmensa variedad, pero no son un puro caos, hay regularidades, clausuras, funcionalidades que podemos intentar describir. En esta descomposición analítica de los aclos humanos no encontramos en un primer momento animales, vida, personas, números, ficciones, conceptos, una conciencia o un decurso histórico, sino que, en todo caso, esto es lo que la razón va deslindando en la impresionante $\mathrm{c}$ inagotable riqueza de notas que se nos presentan. El lenguaje no agota lo real ni nunca acaba de dar cuenta de ello. Es más, el lenguaje se constituye gracias a la constitutiva alteridad de lo notado en los actos humanos ${ }^{4 k}$.
Entre estas notas, aquellas que forman constelaciones de cosas (mi mano, el ordenador, el vaso, el dolor en la muela) son lo que podríamos llamar notas de índole cualitativa. Otras notas son de índole afectiva (tristeza, alegría, etc.) y volitiva (atracción, aversión, querer esto o lo otro). Es posible que debido a la estructuración cultural de nuestras percepciones, no todas las culturas aprehendan los mismos sistemas de cualidades sensibles, tampoco para el niño de dos años las cosas tienen el mismo aspecto que las cosas para un adulto ${ }^{49}$. Sin embargo, lo que se da en todo acto humano es una constelación más o menos clausurada de notas. Por sensación entendemos aquí la simple actualización de una unidad de cualidades sensibles ${ }^{50}$. No hay posibilidad ninguna de tener una sensación que no vincule un sentimiento más o menos borroso (sentirse bien, mal, a gusto o a disgusto $)^{51}$ y una volición. En ese sentido, habrá que decir que aquí no se trata de un sensismo, ni aún en la acepción zubiriana ${ }^{52}$, donde toda sensación vincula un momento de realidad, y tampoco, claro está, de un sentimentalismo o un voluntarismo, sino justamente de una filosofía de la acción que no ve modo de privilegiar en el punto de partida la sensación respecto al sentimiento y la volición ${ }^{53}$.

47. "Hay que atender lan sólo a ser meramente noto. Podría llamarse a esto también cualidad; pero la nota no es siempre de índole cualitativa. Si veo tres puntos, "tres" no es una cualidad, pero es nota. Aun así ha de huirse de pensar que la nola es necesariamente nota "de" algo, por ejemplo, que el color sea color de una cosa. Si veo un simple color, este color no es "de" una cosa, sino que "es" en sí la cosa misma: el color es noto en sí mismo. Es verdad que muchísimas veces llamo [en mis libros] a las notas cualidades, pero es en sentido lato. En sentido estricto nota no es cualidad, sino algo meramente noto; es pura y simplemente lo presente en mi impresión". Cfr. X. Zubiri, Inteligencia y realidad, op. cit., p. 33.

48. Cfr. X. Zubiri, Inteligencia y razón, op. cit., p. 87.

49. Cfr. X. Zubiri, Inteligencia y realidad, op. cit., p. 177.

50. Podrá objetarse que en toda aprehensión va de la mano el mundo de la vida y el lenguaje, pero eso no impide una distinción analítica entre lo inmediatamente dado (cosa real) y la estructuración perceptiva de lo dado. Lo dado no es sin más un caos de notas, sino sistemas más o menos clausurados.

51. Cfr. X. Zubiri, El hombre y la verdad, Alianza Editorial, 1999, p. 122.

52. Cfr. X. Zubiri, Inteligencia y razón, op. cit., p. 89. La gran dificultad del sensismo zubiriano es que fácilmente nos puede llevar a un intelectualismo de nuevo cuño donde los actos intelectivos, los actos de aprehensión, tengan prioridad sobre los otros actos. Es el gran mérito de A. González librarnos de este error no por una especie de interés extrafilosófico, sino apelando, como en Zubiri, al análisis de los actos humanos y de lo actualizado en los mismos. Cfr. A. González, Estructuras de la praxis, op. cit.

53. A diferencia del idealismo hegeliano, donde la aparente riqueza de la sensibilidad es debida a su absoluta vaciedad e indeterminación en el planteamiento zubiriano, la sensibilidad tiene una inamisible riqueza y no hay razón que pueda vaciar exhaustivamente lo inmediatamente dado en los actos humanos. "En rigor, la irreductible individualidad misma de lo intuido es un límite inaccesible a toda evidencia". Cfr. X. Zubiri, Inteligencia y logos, Madrid: Alianza Editorial, 1982, p. 244. 
No hay ningún acıo humano puro de sensación, alección o volición. De hecho, el acto no es más que un momento de la acción humana, un momento que deslindamos analíticamente del hecho inconcuso de la unidad de la acción o proceso sentiente humano ${ }^{54}$. Pero si en una determinada acción hay una dominancia de las notas de índole cualitaliva sobre las notas de índole afectivas o volitivas o a la inversa, podemos hablar legítimamente de actos de sensación, afecciones y voliciones 55 .

El momento material de los actos humanos consistiría en que en ellos, además de notas afeclivas o volitivas, encontramos sistemas de cualidades sensibles que es a lo que en una filosofía primera podemos llamar cosas materiales. Las cosals como sistemas de cualidades sensibles son lo que llamamos cosas materiales: "cosa material es lo percibido, son las cualidades sensibles, como siendo realidad, como siendo algo en propio. Las cosas materiales son las cosas cuyas cualidades son las cualidades sensibles" ${ }^{\text {st. El }}$ adjetivo material aquí solo se reliere a la constelación unitaria de notas sensibles: peso, color, tamaño con que quedan las cosas en los actos humanos. Los sueños, las fantasías, la reflexión, etc. ${ }^{57}$, tienen así una base material en el mismo análisis de actos. La intelección de toda realidad, ya sea externa o interna, liene como momento intrínseco y formal suyo un momento material.

Tanto el materialismo histórico como el metafísico pertenecen al orden de las explicaciones más que a una descripción de lo inmediatamente dado en los actos humanos. Tampoco se trata aquí de defender un materialismo gnoseológico, sino de la descripción del momento material de los actos humanos "anterior" a toda tesis metafísica o epistemológica. Engels indica, a propósito del distanciamiento de Marx respecto a la filosofía hegeliana, que Marx se decidió "a concebir el mundo real - la naturaleza y la historia - tal como se presenta a cualquiera que la contemple sin quime-

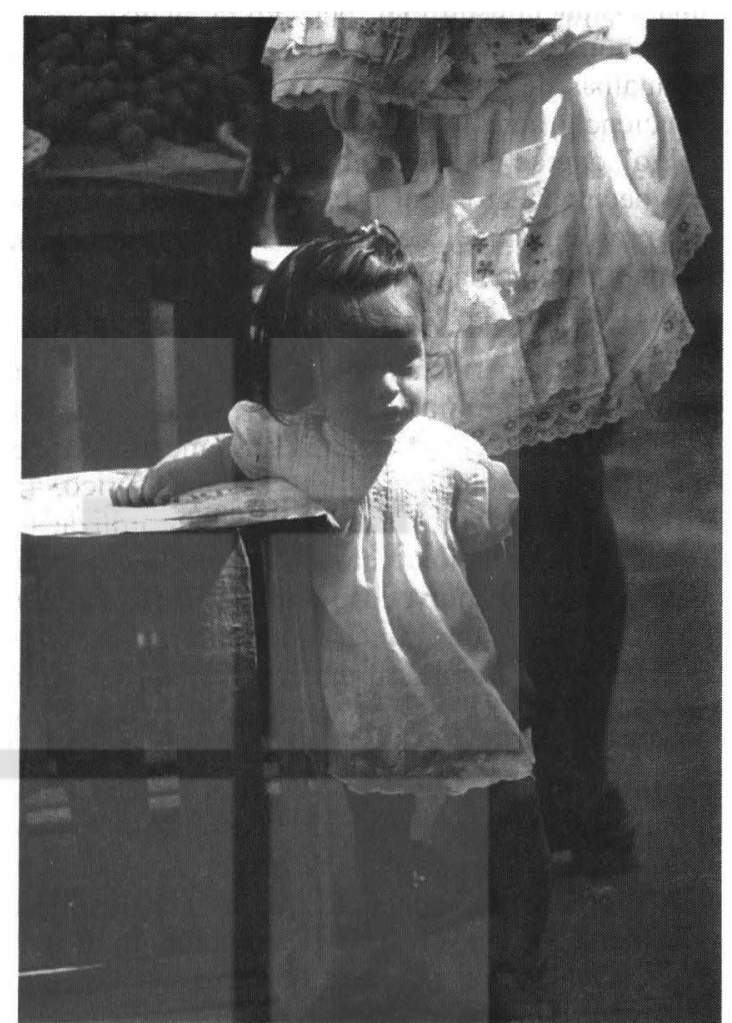

ras idealistas preconcebidas, decıdıencose a sacrıficar implacablemente todas las quimeras idealistas que no concordasen con los hechos, enfocados en su propia concatenación y no en una concatenación imaginaria. Y esto, y sólo esto, es lo que significa el materialismo"s8. Así definido, la praxeología, con su esfuerzo por analizar las cosas mismas prescindiendo de elaboraciones teóricas, podría ser entendida como un materialismo estricto.

En cierto modo, nos encontramos muy cerca de la radicalidad con que Hume plantea su análisis de las impresiones ${ }^{59}$. Como Berkeley ${ }^{60}$, la praxeología también pone en duda la existencia de una sustancia material; pero a diferencia de Berkeley, cuestiona que sea obvio sin más la existencia de

54. Por más autonomía que cobren en el animal humano los tres momentos del proceso accional, nunca se rompe la unidad estructural del sentir. Cfr. X. Zubiri, Inteligencia y realidad, op. cit., p. 41.

55. A. González, Estructuras de la praxis, op. cit., p. 87.

56. Cfr. X. Zubiri, Espacio. Tiempo. Materia. Madrid: A. Editorial, 1996, p. 334.

57. Cfr. X. Zubiri, Espacio. Tiempo. Materia, op. cit., pp. 406 y ss.

58. F. Engels, L. Feuerbach y el fin de la filosofia clásica alemana, Ed. en lenguas extranjeras, Moscú, p. 40.

59. Cfr. D. Hume, Treatise of Human Nature, Oxford, 1967.

60. Cfr. G. Berkeley, A Treatise Concerning the Principles of Human Knowledge, Indianapolis, 1982. 
una sustancia espiritual, pues en el análisis de los actos tampoco la encontramos. Podrá decirse que el análisis de los actos presupone un sujeto o una conciencia ante la cual se actualicen las notas o "algo" que se actualice en ellos. Sí, todo esto podrá decirse. Pero aquí estamos ya en el orden de los presupuestos y de lo explicativo y no ante la verdad primigenia que nos arroja el análisis de los actos mismos.

Se podría perfectamente objetar por qué seguir utilizando el término "material", cuando su uso comparado con el del materialismo metafísico y el materialismo sociológico es casi metafórico. Es difícil crear vocablos nuevos y si bien utilizar un vocablo tan tradicional como "material" puede invitar a muchos equívocos, también tiene la ventaja, en este caso, de apuntar al terreno en que surge la discusión. Además, al intentar depurar el término "material" de todo su aparato metafísico y sociológico, mostraríamos algo decisivo: que en el punto de partida no estamos en un terreno totalmente neutro entre materia y espíritu y, sobre todo, las tesis espiritualistas perderían el bastión más propio e inexpugnable que ha consistido en considerar los actos reflexivos como punto de partida $^{61}$. "Antes" de entrar en nosotros mismos está el carácter material de los actos humanos.

A la hora de conceptuar filosóficamente la materia en una filosofía de la naturaleza, se ha tendido a hacerlo desde la oposición materia-espíritu o, si se quiere, desde la oposición cosa material-cosa espiritual, y esta manera de plantear el problema es justamente lo que niega una filosofía primera, pues en el análisis de nuestros actos no hallamos ninguna constelación de notas espirituales. Que exista o no exista es otro problema, pero una teoría metafísica que tenga en cuenta los resultados de la praxeología no puede partir de una división entre una zona de cosas materiales y una zona de cosas espirituales. No es un imposible metafísico que, "allende" los actos, las cosas sean espirituales y evanescentes, pero si alguien defendiera que todo es un sueño y que lo que comúnmente llamamos sueño no es más que un soñar que soñamos, es posible hacerle notar que eso no niega la alteridad primordial con que quedan todas las cosas en nuestros actos ni la "materialidad" primigenia de los mismos, y que es por esta alteridad radical y por esta "materialidad" del sueño que se ve empujado a afirmar la problemática tesis metafísica, al menos en la cultura occidental, de que la esencia del cosmos sea fantasmagórica.

Estamos seguros de la materialidad de los actos, pero no estamos igualmente seguros de una realidad material o de una realidad espiritual exterior a los mismos. Aquí equidistamos tanto de un realismo metafísico como del idealismo moderno. ¿Pero no caeríamos en una especie de solipsismo praxeológico trascendental? ¿El hambre, la necesidad de respirar, de afectos, las necesidades fisiológicas, no prueban suficientemente la existencia real $e$ independiente de algo otro que lo actualizado en los actos mismos? ¿Los mismos actos no presuponen un agente o un actor de los mismos? Ciertamente, la apelación a necesidades humanas, como beber y respirar, parece que tienen una mayor fuerza de imposición que las imágenes de la vista. El tacto, el dolor, la temperatura, son sentidos con una fuerza de imposición de lo real mucho más poderosas que la vista. Siempre puede sospechar uno que lo que ve son fantasmas o espectros, pero no así un pellizco o el hambre o el trompazo con una roca, por más que en los sueños también se da ello. Pero el que algunas formulaciones idealistas se hayan basado más en la vista que en otros sentidos (gusto, tacto) no rebate su argumento fundamental y más poderoso, que es que puedo dudar de todo, excepto de la inmediatez del pensamiento y de la conciencia. En cambio, en la praxeología puedo dudar también de esto, pues lo que encuentro primariamente son constelaciones de notas ${ }^{62}$. En el marco de una praxeología trascendental no está primaria ni radicalmente justificada la división entre "sujeto" y mundo real objetivo "fuera" del mismo, ni el sujeto goza de ninguna prioridad sobre la realidad allende o a la inversa. La escisión entre el mundo del llamado "sujeto" y el mundo real "fuera" del mismo no es más que un prejuicio metafísico no justificado. En realidad, "todo lo que la ciencia afirma del mundo físico sólo está justifi-

61. Cfr. J. Ortega y Gasset, ¿Qué es conocimiento? Madrid: Alianza Editorial, 1984; X. Zubiri, Espacio. Tiempo. Materia, op. cit., p. 406.

62. Este delito del idealismo, el considerar que hay actos inmediatos a sí mismos, es sorprendido por Ortega. Cfr. J. Corominas, "La insatisfacción con el punto de partida de Ortega", Etica primera, op. cit., pp. 229-232. 
cado como explicación de lo percibido en cuanto real 'en' la percepción" "63, y lo que radicalmente está en ellas son notas materiales y notas de índole alectiva y volitiva, remitiendo a sí mismas y abriendo, en esta remisión, su esencial problematicidad.

\section{De la filosofia primera a la metafísica}

Hasta aquí hemos operado con dos nociones de "materialidad", uno analítico, lo material en el análisis de los actos humanos: "cosa material es lo percibido, son las cualidades sensibles, como siendo realidad, como siendo algo en propio" $"$, y otro propio de la teoría racional que es la materia "allende". Fijémnonos en que el trampolín del análisis no es totalmente aleatorio respecto a las trayectorias tcóricas posibles. El punto de arranque de la filosofía es decisivo. No es lo mismo que el discurso lilosófico parta de una teoría sobre el cosmos que de un análisis de los actos.

En el primer caso, la arbitrariedad y la opción crecen a la par de la fucrza explicativa y de la sistematicidad; en el segundo caso, la arbitrariedad y la opción se adelgazan a la par de una verdad nimia y extraordinariamente abierta. Ahora bien, esle nivel radical del discurso lilosófico proyecta una nueva luz sobre los demás niveles. La alteridad con que quedan todas las cosas en nuestros actos nos lanza a preguntarnos por lo que son esas cosas más allá de los mismos. Las cosas, por quedar "de suyo" en la aprehensión, quedan también abierlas de manera casi absoluta y su enigmaticidad y problematicidad nos arrastran. La marcha, la profundización o la inmersión en esta realidad con que quedan las cosas en la aprehensión depende, sin duda, de una mentalidad, un acervo cultural, unos recursos económicos y un sinfín de otros faclores. Una de las trayectorias que goza de mayor fuerza al mundializarse la cultura occidental es justamente la científica. El esfuerzo por ir determinando cuáles son las implicaciones materiales de los actos humanos sería el campo propio de las teorías científicas.

Es muy posible que el hecho de que un filósofo como Zubiri haya partido de una experiencia científica más que de una experiencia artística y literaria tenga su impacto en su filosofía ${ }^{6.5}$. No resulta nada extraño que una mentalidad artística o poética se halle incómoda ante una filosofía que aparentemente lidia sobre todo con nociones científicas. En cualquier caso, el conocimiento para $\mathbf{X}$. Zubiri no es sólo ciencia ni tampoco es principalmente ciencia. Hay diferentes actividades cognoscitivas que, según la realidad de que se trate, pueden dar mejor o peor cuenta de ella. En resumidas cuentas, lo que trata Zubiri es de poner a la ciencia y a los diferentes tipos de actividad racional en su lugar. Y cste "lugar", el punto en que coinciden toda esta diversidad de líneas y de direcciones cognoscitivas, consiste en ser un lanzamiento a lo que pueda ser lo real en profundidad. Adviértase que no estamos en la clásica dicotomía sujeto-realidad, sino entre una realidad actualizada y una realidad "allende". Tan "allende" se encuentran de la realidad actualizada hipótesis como las de la "conciencia" o "persona" como la de "cosmos" material por más plausibles que puedan ser. "El allende no es tan sólo un concepto teórico, como lo son la onda o el folón. El allende puede ser también lo que forja una novela; no la forjaríamos si lo real dado no me diera que pensar. Lo propio debe decirse de la poesía: el poeta poetiza porque las cosas le dan que pensar. Y esto que así piensa de ellas es su poesía. Que lo inteligido así sea una realidad teoréticamente conceptuada o sea realidad en ficción, o sea realidad poética, no cambia la esencia de la intelección como razón" "๙ .

La praxeología no privilegia ni la metafísica ni la ciencia ni el arte como vía de acceso a lo real. Cada vía liene su especificidad, sus insuficiencias y pueden recubrirse con otras. Para Zubiri, las ciencias estudiarían los contenidos positivos de las cosas reales, mientras que la metafísica estudiaría estas mismas cosas reales en cuanto formas de realidad. Y con ello se opondría tanto al positivismo científico, que acaba considerando que toda realidad es inmediatamente accesible al dato positivo de la ciencia y que la mera consideración científica es suficiente para determinar la totalidad

63. Cfr. X. Zubiri, Inteligencia y realidad, op. cit., p. 186.

64. Cfr. X. Zubiri, Espacio. Tiempo. Materia, op. cit., p. 334.

65. Gramsci insinuará que el filósofo-literato es más "realista" que el filósofo científico, en la medida en que parte de un ser humano intelectualmente activo y no tiende a reducirlo a parte de la naturaleza. Cfr. A. Gramsci, Introducción al estudio de la filosofia, op. cit., p. 179.

66. Cfr. X. Zubiri, Inteligencia y razón, op. cit., p. 43. 
de la realidad en cuestión, como a los filósofos que, anclados en el ser, en la trascendentalidad, pretenden ignorar las investigaciones científicas. La tcoría metafísica avanzaría a la par y con la misma provisionalidad que las teorías científicas. Sin embargo, hay un nivel de radicalidad mayor, un campo donde la filosofía es máximamente autónoma. Se trata del campo analítico de la praxeología que se esfuerza en el análisis por prescindir de toda teoría metafísica. Ese nivel no negaría la teoría metafísica, sino que le proporcionaría un subsuelo. Es justamente en este nivel desde donde se puede desarrollar un diálogo crítico con las ciencias y con las mismas teorías metafísicas. Se trata juslamente de mostrar los presupuestos melafísicos con los que siempre estamos desarrollando las teorías.

En el análisis de los actos humanos podemos distinguir algunos hechos positivos, aquellos hechos que, por su propia índole, son aprehendibles por cualquiera. Por ejemplo, un determinado color o un sonido. El hecho científico es una fijación de estos hechos desde un sistema de conceptos previos, propios de cada ciencia ${ }^{67}$. No es lo mismo la materia para un físico que para un biólogo. Ni se conceptúa igual en la física newtoniana, en la de Einstein o en la física cuántica. Hay siempre factores históricos y sociales que determinan la elección de conceptos desde los que se fijan los hechos. El método científico parte de un sistema de referencia constituido por los hechos actualizados en la aprehensión y por el sistema conceptual de que dispone una determinada ciencia ${ }^{68}$.

Lo mismo podríamos decir de una teoría metafísica trascendental. También aquí partimos de los hechos actualizados en nuestros actos y de un sistema conceptual que, en este caso, es el de las diversas teorías metafísicas. Estas teorías consideran los mismos contenidos que consideran las ciencias desde una perspectiva transcendental. Esto es, desde el momento de alteridad o realidad de estos contenidos. Pero, a diferencia de las teorías científicas, las hipótesis y las tesis metafísicas no son objeto de experimentación, sino de plausabilidad, dadas unas determinadas constataciones científicas. Eso hace que los científicos puedan coincidir en los resultados de su ciencia, pero diferir grandemente en la interpretación metafísica de los mismos. Por eso hay físicos y biólogos que son materialistas, otros son idealistas y un largo etc. Además, los conceptos de una teoría metafísica de carácter zubiriano, provengan de donde provengan, son medidos y acrisolados por su propiedad o impropiedad a la hora de analizar y de dar cuenta con ellos de lo actualizado en los actos humanos. Nociones como función, sustantividad, campo, nota, "de suyo", pueden provenir de cualquier juego lingüístico, de teorías científicas o de la literatura, pero si estos términos son impropios para describir lo inmediatamente actualizado en la aprehensión, mucho menos podrá esperarse que lo sean para elaborar con ellos una teoría metafísica. Una metafísica de carácter zubiriano se levanta tanto desde el esfuerzo descriptivo y analítico de una filosofía primera, como de tomarse absolutamente en serio el avance de las diversas disciplinas científicas. Aunque las conceptuaciones metafísicas no se fundan en la ciencia, los logros de ésta no son ajenos a la filosofía. La metafísica atiende por encima de todo a aquellos conceplos científicos que podrían envolver alguna connotación para una teoría de la realidad, en tanto que realidad. En este sentido, los logros científicos pueden constituir una fecunda inspiración filosófica. Y por su parte, la filosofía puede desprender a las ciencias de adiposidades metafísicas, que a menudo atenazan y constriñen la investigación científica.

La praxeología es también muy útil para liberar a la filosofía del arte de muchos presupuestos que llegan a considerar esta actividad racional

67. "Para que un hecho sea científico, lo observable para cualquiera ha de estar en cierto modo fijado". Cfr. X. Zubiri, Inteligencia y razón, op. cit., p. 184.

68. A. González, "Hacia una fundamentación de las ciencias sociales", Para una filosofía liberadora, pp. 65-96. 
como una actividad de segundo orden respecto a la actividad científica y que pueden atenazar o acomplejar de algún modo la creación artística y literaria. Recíprocamente, la creación artística y literaria, mucho menos afanosa por explicar y apresar la realidad profunda, puede liberar a la filosofía primera y a la metafísica de una pretendida búsqueda de seguridad y del privilegio de una vía conceptual respecto a una vía ficticia o fantástica para acceder a lo real.

\section{La filosofia de la naturaleza zubiriana: el materismo}

Uno de los múltiples problemas de la investigación racional, que necesariamente sobrepasa el marco de una praxeología, consiste en plantear una teoría sobre la realidad en tanto que realidad. Es el sentido propio que aquí otorgamos al término "metafísica". Una filosofía de la naturaleza constituiría uno de los capítulos privilegiados de la metafísica. El problema del espacio, el tiempo y la materia, que es abordado a su modo por las diferentes disciplinas científicas (geometría, matemática, física, astronomía, biología, etc.,), podría ser lambién objeto de una investigación metafísica. Como ya hemos destacado en el apartado anterior, la distinción entre la consideración científica y la consideración metafísica no supone independencia total, sino más bien enriquecimiento mutuo. Tomarse en serio las investigaciones científicas hace avanzar a la teoría metafísica y evita tanto su tentación de absolutez como su acantonamiento subjetivo y arbitrario.

Por su lado, los científicos, al tomarse en serio la investigación metafísica, pueden ser mucho más libres en su investigación, pues no se ven forzados a cargar con preconcepciones sobre lo real que pueden lastrar sus tesis científicas, y pueden también aspirar a ir situando los logros científicos en una perspectiva global, que escapa de algún modo a la perspectiva de cada disciplina científica.

El problema sobre las estructuras fundamentales de las cosas arranca del carácter sentiente de la razón. ¿Qué podemos decir que son las notas materiales sentidas en nuestros actos más allá de los mismos? Son los mismos actos racionales los que van dotando a la realidad de un contenido estructural libremente creado $^{69}$. Lo que sean las cosas en última instancia es siempre un problema abierto. Lo que no es problema sino un hecho es la apertura mundanal de todos nuestros actos. En nuestros actos sentimos ya el mundo. El mundo es la respectividad misma de lo real o, si se quiere, la constitutiva apertura de las cosas a toda otra cosa. Esta apertura es constitutiva. Aunque llegáramos a precisar con detalle y minuciosamente todas las cosas y estructuras que constituyen el mundo, nada colmaría ni cerraría esta apertura. La razón sentiente es así lo contrario de una razón totalitaria e integradora. Lo que sean cósmicamente, esto es, como contenido del mundo, las cosas actualizadas en aprehensión es siempre algo provisional y término de una actividad racional. El cosmos como tal no es necesario ${ }^{70}$. No lo es ni científicamente, pues anterior al estado inicial del cosmos podrían haber otros cosmos, ni lo es metafísicamente, pues en toda teoría metafísica, el cosmos sigue siendo lo sentido en tanto que pensado y esbozado por la razón.

Ninguna tesis sobre el cosmos tiene la fuerza de imposición de la verdad real, de lo sentido. Eso no impide que no se pueda defender, como $\mathbf{X}$. Zubiri, una tesis "materista" que equidista tanto de todo tipo de materialismo como de todo tipo de dualismo entre una sustancia material y una sustancia espiritual. El materismo es la tesis de que todo procede de la materia y de que nada en el cosmos es independiente de ella, pero a diferencia del materialismo, no todo en el cosmos es exclusivamente material. Es muy fácil reducir el "materismo" zubiriano tanto a un materialismo como a un dualismo un poco más sofisticado. La tesis materista zubiriana es muy problemática y en lo que sigue vamos a ver algunos de estos problemas, pero se hace un flaco favor filosófico a la novedad de esta tesis acantonándola hacia otras tesis metafísicas, que no porque sean más conocidas son menos problemáticas.

$X$. Zubiri se inclina a pensar que el curso del cosmos sería simplemente la variación de momentos de una unidad primera, algo así como la unidad del curso de una melodía" ${ }^{7}$ La unidad de cada cosa real sería como una expansión por multiplica-

69. Cfr. X. Zubiri, Inteligencia y razón, op. cit., p. 117.

70. Ibid., p. 283.

71. Ibid., p. 116 
ción de la unidad primaria del cosmos. La metáfora que utiliza $X$. Zubiri es la de una melodía dinámica que se va haciendo en sus notas. Por un lado cstarían las notas, las cosas naturales (natura naturata). Por otro lado, su unidad primaria (natura naturans) o principio activo. Del mismo modo que los momentos de una melodía no se hallan en interacción con otros momentos de ella, y, sin embargo, hay un curso melódico de estructura perfectamente determinada, la unidad del cosmos no sería láxica sino melódica según leyes deterministas y de probabilidades ${ }^{72}$. La escisión del cosmos en cosas realmente distintas no pasaría, pues, de ser una escisión provisional.

En la realidad, todas las sustantividades serían provisionales, con excepción de la sustantividad del cosmos. Un átomo puede ser considerado como una sustantividad provisional en la glucosa. La glucosa como una nota o sustantividad provisional del organismo humano y el organismo como una sustantividad provisional dentro del sistcma social. Tanto la glucosa, como el organismo, como los sistemas sociales, todo sería meras sustantividades provisional en la sustantividad del cosmos. Pero la sustantividad humana tendría la peculiaridad, por su apertura a toda la realidad, de no estar plenamente integrada en el cosmos por más que lo esté su organismo ${ }^{73}$. La sustantividad cósmica tendría una esencia o estructura constitutiva material. La materia para Zubiri no es una sustancia sino una sustantividad o constructo de notas. Es propiamente la estructura constitutiva de las cosas materiales ${ }^{74}$. Existirían distintos tipos de materia, según las distintas formas de estructuración o notas que la constituyen. Habría una materia elemental, la de las partículas elementales y la de la energía, donde la matcria no se identifica con corpúsculos. Habría otra materia corporal (átomo, molécula) que a su vez se presentaría en distintos subtipos (sólido, líquido, gaseoso). Después emergería la materia viva (virus, viroides), la materia biológica (organismos), la materia sentiente (sistema nervioso, animales) y, finalmente, una materia que formaría sistema con notas no-materiales. Se rían los sistemas psicoorgánicos humanos que, por su apertura a lo real en la aprehensión, el sentimiento y la volición, contarían con unas nolas nomateriales.

Dinámicamente considerada, la materia scría capacidad de dar de sí. La materia daría de sí produciendo por transformación algunas notas o partículas clementales nuevas (parlículas elementales de la física). Por sistematización, la materia daría de sí nuevas realidades con propiedades que no serían el resultado aditivo de las propicdades de las notas que entran en ella, sino propiedades de todo cl sistema (vida, organismo, sensibilidad animal) $)^{75}$. Y, finalmente, por elevación, la materia se abriría a lo real dando de sí sustantividades transcósmicas (esencias abiertas, personas). En los dos primeros dinamismos la materia daría de sí por sí misma. En el tercero daría de sí por otro: "la evolución a lo psíquico, a la apertura a lo real o a la conformación de un sistema con notas no-materiales está hecha por la transformación de las estructuras celulares animales, pero no está hecha por ellas por sí mismas"76. El poder de elevación sería del cosmos mismo. La natura naturans es la que haría, en una acción intrínseca, que las estructuras celulares se clevaran a notas psíquicas. Desde la materia, por "elevación", a partir del poder de la unidad dinámica del cosmos, se constituiría una sustantividad que ya no sería estrictamente material en todas sus notas. Para X. Zubiri sería impropio llamar a la sustantividad psicoórganica materia inteligente. No es sólo una cuestión terminológica, sino una imposibilidad metafísica: la materia no puede dar por sí misma una sustantividad transcósmica. La historia y la libertad humana serán todo lo efímera que se quiera y no podrán prescindir de lo material, pero no son reducibles a lo material ni son parangonables a los dinamismos más sofisticados y complejos de la materia.

La materia no puede dar de sí, por sí misma, algo que le es absolutamente heterogéneo. No se

72. Ibid., p. 116.

73. Cfr. X. Zubiri, Inteligencia y realidad, op. cit., p. 213.

74. Cfr. X. Zubiri, Espacio. Tiempo. Materia, op. cit., p. 346. No se puede considerar tampoco aristotélicamente a la materia como un principio de indeterminación. Zubiri considera que no hay más materia que la que el mismo Aristóteles llamó materia scgunda, la cosa material a secas.

75. Ibid., p. 587.

76. Ibid., p. 604. 
Irala aquí de decir que un cambio gradual acaba siendo esencial. Esto podrá decirse de los procesos de sistematización, pero no del proceso de hominización, pues no hay ninguna complejidad de eslímulos que pueda producir el salto a la formalidad de realidad ni ninguna sistematización de notas que pueda dar de sí, por sí misma, notas intelectivas, es decir, inmateriales. Podría pensarse que sc trata de una especie de remilgo teológico para dejar la puerta abierla a una intervención de Dios. Es lo que apunta P. Laín Entralgo ${ }^{77}$. Sin embargo, no lo pienso así. La teología siempre podrá acomodar los descubrimientos científicos respecto a la génesis del hombre argumentando que Dios, origen de todas las cosas, lo creó a través de las causas segundas, ínsitas en el universo y que no tiene necesidad, por tanto, de una intervención creadora especial. Creo que hay que liberarse de pensar estas cuestiones con intereses teológicos y no sólo por el bien de la filosofía, sino por el bien de la teología. Si zubirianamente llegáramos a afirmar que Dios es realidad absolutamente absoluta, habría aún que ver que liene que ver eso con el Dios de las religiones.

La alternativa que propone Laín de pensar un materialismo estructurista donde surge por sistematización, al igual que la vida, una materia inteligente, creo que nos aleja de lo más propio del materismo zubiriano, acercándolo al materialismo, y Zubiri afirma una y otra vez que lo suyo no es materialismo: "El materialismo consiste en afirmar que todo lo real y todas sus notas son de estructura exclusivamente material. Y esto es falso"7\%. "Toda realidad, tanto la puramente material como la no puramente material, nace en el seno de la materia, en función determinante de la materia, y tiene un momento constitutivo intrínseca y formalmente material. Ahora bien, esto no es materialismo. El materialismo consiste en afirmar que todo lo real y todas sus notas son de estructura exclusivamente materiales. Y esto es falso. ¿Cómo se va a decir que la inteligencia, el sentimiento y la voluntad, como potencias, son potencias de estructura mate- rial? Esto es imposible"79. Si el término "materia" acaba significándolo todo y si puede hasta hablarse de materia angélica, entonces obviamente tampoco significa nada. El materismo nos posibilita pensar la radical heterogeneidad de notas orgánicas y notas psíquicas, sin recaer en un nuevo dualismo. Y tal vez su dificultad no resida tanto en su propia dificultad interna como en su novedad frente a las categorías clásicas, que nos atenazan al delinear una teoría metafísica.

Para Zubiri, lo psíquico es no sólo lo opuesto a lo orgánico, sino lo opuesto a lo material. Si todo lo que aprehendemos son cosas materiales, las notas psíquicas son aquellas notas que justamente postulamos que tiene que haber para aprehender las cualidades sensibles como reales. No nos encontramos ante un nuevo sustancialismo, ante la tesis de que el cosmos está conformado por una única sustancia de la que emergerían las potencias y las facultades superiores (tesis emergentista), ni incurrimos en un nuevo dualismo o afirmación de la existencia de dos sustancias independientes (res extensa y res cogitans), pues para $\mathrm{X}$. Zubiri, por más que las nolas intelectivas sean irreductibles a la materia, no pueden ser una sustancia o un elemento capaz de unirse o separarse del cuerpo (alma). La realidad sustantiva es sólo una y lo psíquico sólo es real en el interior de la sustantividad humana. En la sustantividad humana, las notas físico-químicas u orgánicas y las notas psíquicas o que envuelven un momento de realidad conforman una radical unidad. Todo lo orgánico es psíquico y todo lo psíquico orgánico. Las notas psíquicas se constituyen "desde" las estructuras materiales mismas, pero no por sí mismas. Sólo el todo cósmico puede, por sí mismo, constituir desde la materia una sustantividad como la humana que ya no es estrictamente material. La natura naturans es la que hace que la materia dé de sí, por elevación, algo que trasciende los dinamismos materiales.

La cuestión filosófica decisiva es la eliminación de un pensamiento sustancialista que amara tanto la tradición materialista en la que, al final, el

77. P. Laín Entralgo, Cuerpo y alma, Austral, 1991, p. 192 y ss. Puede que en los años cuarenta la posición de X. Zubiri se acercara a la del aristotelismo católico y podría entenderse la "elevación" como una reminiscencia de la "causa exigitiva", pero más bien creo que hay que entender la "elevación" desde la coherencia exigida por su sistema metafísico.

78. Cfr. X. Zubiri, Espacio. Tiempo. Materia, op. cit., p. 411.

79. Ibid., p. 411. 
psiquismo humano es concebido como un psiquismo animal más evolucionado y complejo, con toda la autonomía que se quiera, pero no esencialmente dislinto que el del animal, como la tradición idealista, donde la irreductibilidad de las notas intelectivas lleva a afirmar una pluralidad de sustancias. Zubiri afirmará con los idealistas que el psiquismo humano es esencialmente distinto del animal, pero con los materialistas, no entiende el psiquismo como cualidad extrínseca a la materia. El "materismo" de X. Zubiri nos libra tanto de aquellos planteamientos que consideran que hay algo "superior" como es la inteligencia, la voluntad y el sentimiento que reposa sobre sí mismo, y donde lo "inferior" (lo orgánico, lo corpóreo, etc.) quedaría a las espaldas, como de aquellos planteamientos que consideran el nivel superior como mero resultado más complicado de la actividad de los niveles inferiores ${ }^{\mathrm{k} 0}$. Al pensar en lérminos de sustantividad y no de sustancialidad, es posible afirmar que existen sistemas con notas totalmente heterogéneas que forman una unidad sistemática sin tener que reducir alguna de ellas a la otra y sin tener que asumir tesis dualistas.

Que el cosmos, entendido como la unidad de todas las cosas reales, la natura naturans, el universo o el todo sea lo único que podamos pensar como sustantivo, no plantea mayor problema dentro de la lógica misma del materismo zubiriano. El problema consiste en afirmar que el cosmos tiene una esencia o estructura constitutiva material. Dentro del mismo plexo de categorías zubirianas es muy problemática esta sustantividad estricta material del cosmos. Por un lado, en el cosmos encontramos los sistemas humanos que no son exclusivamente materiales, pues tienen notas intelectivas $y$, por tanto, no son del todo integrables en el cosmos, son de alguna manera transcósmicos. Por otro lado, estas notas intelectivas son hechas posibles por una unidad cósmica originaria, la natura naturans, cuya estructura no es exclusivamente material. Por eso, la natura naturans puede dar de sí el ser humano que no es ya una natura naturata exclusivamente, sino una natura naturata naturans. ¿Cómo puede decirse, entonces, que la esencia del cosmos es material?

Si el todo cósmico es la única sustantividad estrictamente dicha que va plasmándose en los diversas sustantividades provisionales, este $\operatorname{todo}^{\mathrm{RI}} \mathrm{o}$ no es material o si es material no tiene sustantividad estricta. La aparente contradicción podría deberse a una cierta ambigüedad en el uso del término cosmos y a un indiscernimiento entre cosmos y mundo perceptible en muchos textos y no aclarado y precisado hasta sus últimas obras y artículos. En sentido estricto, cosmos es la unidad talitativa de lo real, pero a veces Zubiri utiliza el término "cosmos" como sinónimo de mundo o de la unidad de todo lo real en tanto que real. Ahora bien, si entendemos por "todo" o natura naturans el mundo en sentido estricto, podemos decir que este "todo" tiene un contenido talitativo ${ }^{82}$, que es a lo que propiamente podemos llamar cosmos, cuya esencia es material. Pero este "todo" no tiene sólo un carácter material (cósmico), sino también un carácter real (mundanal), abierto. De esta suerte, el devenir de cada una de las cosas y del cosmos material mismo pende de una realidad que es de por sí dinámi$\mathrm{ca}^{83}$. Es la respectividad de todas las cosas reales en cuanto reales la que da pie a la apertura constitutiva de los sistemas o sustantividades humanas y a las notas no materiales de los mismos. Así, podrá decirse que el cosmos tiene esencia material, pero no una sustantividad estricta.

80. "Lo superior no sería sino la mayor riqueza de lo inferior, pero de la misma índole que este... pero entonces no existiría ninguna diferencia entre propiedades naturales y apropiadas". Cfr. X. Zubiri, Sobre el hombre, Madrid: Alianza Editorial, 1986, p. 515.

81. Cfr. X. Zubiri, Espacio. Tiempo. Materia, op. cit., p. 427.

82. Cfr. X. Zubiri, Espacio. Tiempo. Materia, op. cit., p. 486 y ss.

83. Así lo aprecia P. Laín Entralgo en su último escrito, donde de alguna manera parece distanciarse del materialismo estructurista de su anterior libro Cuerpo y alma, 1991. Cfr. P. Laín Entralgo, Qué es el hombre. Evolución y sentido de la vida, Ediciones Nobel, Oviedo, 1999, p. 185. El problema, a mi modo de ver, es que sigue sin apreciar la radical heterogeneidad entre notas materiales y notas no-materiales al no distinguir entre innovación por sistematización, que es un poder de la materia, e innovación por elevación, que es un poder que trasciende al poder material. Para X. Zubiri, a diferencia del P. Laín Entralgo, el surgimiento de la materia viva con el surgimiento de sustantividades con notas no-materiales (hominización). Cfr. P. Laín Entralgo, ibid., pp. 188-189. 
La física que estudia lo talitativo, en cuanto ciencia, no tendrá que entrar ni salir en ello y puede perfectamente lomar el cosmos como una sustantividad estricta. La cuestión con la metafísica zubiriana es que la realidad es estricta apertura, y aunque no hubiera más que un cosmos, este cosmos está abierto a lo real. La sustantividad más estricta de todas, el cosmos, no deja de estar abierta a lo real. La apertura del ser humano a lo real es posible porque el universo es un cosmos abierto no sólo a otras cosas materiales sino abierto a lo real. A mi modo de ver, aquí se dibuja en líneas generales una filosofía materista de la naturaleza, que nos permite entender los distintos modos de la actividad humana más aceptablemente que las concepciones dualistas y que las concepciones materialistas. Como toda teoría metafísica, por más abierta que sea, no deja de correr siempre el peligro de tratar de encorsetar lo real, pero toda metafísica deja de ser una camisa de fuerza en el momento en que arraiga en una filosofía primera, se fluidifican sus afirmaciones y dejan de verse como una explicación última de las cosas.

\section{Conclusiones}

Es la criticidad de la praxeología la que nos permite la suficiente libertad metafísica como para intentar ser más fieles a la realidad misma que a nuestras ideas sobre ella. Y este esfuerzo por cuestionar radicalmente todo supuesto es, sin duda, el principal mordiente crítico de la filosofía zubiriana. Podrá acusarse a este planteamientu de ser puramente crítico y de no arrojar resultados positivos. Lo apasionante es que en esta voluntad de cuestionamiento ni la crítica ni los resultados positivos se sostienen dogmáticamente, sino por lo que se detecta en el análisis mismo mal nos pese cuando queremos ser sólo críticos o cuando andamos buscando seguridades y certezas. La praxeología, más que proponer una nueva filosofía de la liberación, reconoce, como el mismo I. Ellacuría, que la mejor y más poderosa proyección política, social y económica de la filosofía viene de un esfuerzo por un filosofar sin más ${ }^{84}$. Sobre todo se intenta evitar la trampa saducea que supone afirmar que en el contexto latinoamericano no debemos hacer otra cosa que filosofías prácticas, pues podría ser que así fuéramos siem- pre esclavos de esquemas y nociones ajenas que son más parte del problema que de la solución. El término "liberación" lo hemos usado un poco promiscuamente. En América Latina ha ido asociado en este siglo a grupos, partidos y asociaciones que han intentado realizar transformaciones políticas, sociales y económicas estructurales para sacar de la miseria a las grandes mayorías asumiendo, a su modo, los proyectos emancipatorios ilustrados. Creo que el ejercicio filosófico, cuando es un auténtico esfuerzo en pos de la verdad, es sustantivamente liberador de todo tipo de prejuicios y mordazas, también de los que operan bajo la voluntad de liberación política, económica y social. Una filosofía liberadora, esto es, con pretensiones de transformación económica, política y social, y en general, el carácter interdisciplinario de la filosofía, sale potenciado cuando preserva su núcleo especializado y crítico que, por más tecnicismos que envuelva, no consiste en otra cosa que en el replanteamiento permanente de lo que en un momento determinado se llega a considerar como el objeto más propio del filosofar. ¿Quiere esto decir que las filosofías de la cultura y de la identidad, de la sociedad, de la historia y de la ética, en las que ha menudo ha consistido la filosofía de la liberación, no son importantes para la filosofía latinoamericana? Todo lo contrario. Estas filosofías son importantísimas. Pero es precisamente rehaciéndolas desde una filosofía de la acción que son susceptibles de ganar una densidad extraordinaria.

Para Ellacuría, Zubiri empieza siempre desde una realidad dinámica trascendental, y su mayor virtualidad liberadora consistiría en desarrollar una metafísica en la que tendría cabida la novedad histórica. La praxeología de A. González prolonga la brega intelectual de I. Ellacuría, mostrándonos cómo lo decisivo para una filosofía con pretensiones emancipadoras no es una concepción cosmológica o metafísica unitaria, sino el replanteamiento de toda concepción metafísica, cosmológica, social, epistemológica y científica desde un punto de partida nuevo: desde la praxis. La praxeología no sólo radicaliza todo materialismo metafísico, sino también el materialismo histórico en cuanto se sustenta en un punto de partida antropológico. Eso no significa que no se pueda recuperar ulteriormente el planteamiento de Ignacio Ellacuría y de Grams-

84. Cfr. J. Sobrino, R. Alvarado, I. Ellacuría: ««Aquella libertad esclarecida»>, UCA Editores, 1999, pp. $100-101$. 
ci, pero el orden de los saberes es decisivo y es, en sí mismo, un orden político que nos abre o nos cierra posibilidades liberadoras. La recta politización de la filosofía sc encontraría en este or$\mathrm{den}^{\mathrm{ks}}$. Dicho de otro modo, que la praxis o la acción humana se encardine en una concepción metafísica unitaria no es lo mismo que hacer de la praxis el punto de partida de la filosofía, por más que ulteriormente se pucda considerar que las tesis que deliende I. Ellacuría en La realidad histórica tienen una gran plausibilidad metafísica. No sólo el orden de los factores altera el producto, sino que la radicalidad de la liberación misma podría jugarse en este orden.

Indudablemente, no basta con el potencial liberador propio de la filosofía para transformar una sociedad donde la injusticia y la diferencia social parecen ir en aumento. Para que la semilla libe- radora de la filosofía fructifique es necesario el riego y la tierra de la fraternidad del filósofo con las víctimas de todo poder, por más que no fueran agentes liberadores y por más que no hubiera aquí y ahora una "praxis liberadora" tre una existencia socrática proclive a la soledad, pero necesaria para que la filosofía conserve su mordiente crítico y una existencia fraternal con las víctimas de todo poder proclive al activismo y a la politización de la filosofía y el filósofo, pero necesaria para que la filosofía tenga alguna eficacia liberadora, es al precario equilibrio al que nos invita Ellacuría y que a su modo realizó en su vida. Es un equilibrio difícil para una persona sola, pero que quizás un colectivo de eternos principiantes en filosofía pueden tratar de emular. Este sería el mejor homenaje filosófico que cabría dispensar a $\mathbf{I}$. Ellacuría ${ }^{\mathrm{k} 7}$.

85. I. Ellacuría, "Filosofía y política", Veinte años de historia en el Salvador, Tomo I., p. 120 y ss.

86. Y lo mismo puede decirse del abogado, del administrador de empresas, del periodista, del físico y del ingeniero. El quehacer filosófico no tiene ni más ni menos exigencia ética que cualquier otro saber.

87. Otra cosa es el Ignacio irrepetible y único de carne y hueso, apasionado y polifacético: a la vez político, teólogo, académico y visionario. 